\title{
CALENDARI MÚSICO-LITÚRGIC DE LA CATEDRAL DE BARCELONA, FINALS DEL S. XVII-INICIS DEL S. XVIII
}

Dr. Josep Pavia i Simó

Científic Titular emèrit del CSIC

Canonge Prefecte de Música Sacra de la Catedral de Barcelona

\begin{abstract}
The manuscript "Manuel del Cabiscol" (The Cabiscol Manual) from theArchives of the Barcelona Cathedral (16821729) contains all the rulesthat were enforced in the said cathedral from time immemorial, relatingto the dignified and solemn enactment of the worship in the said Cathedral. The manuscript includes even the smallest details pertainingto the ceremonies and rites carried out in the Choir, the altar and even in the processions held outside the church, following the requirements of the solemnities of the liturgical year. In this study we shall be selecting from the said "Manual" all that refers to the all important musical participation in each of the said solemnities.
\end{abstract}

\section{Resumen}

El manuscrito "Manual del Cabiscol" del Archivo de la Catedral de Barcelona (1682-1729), contiene todas las normas que regían en dicha Catedral desde tiempos inmemoriales, concernientes al digno y solemne desarrollo del culto de dicha Catedral. En él se recogen hasta los más mínimos detalles de las ceremonias y ritos de todos los actos realizados en el coro, en el altar e incluso en las procesiones fuera de la iglesia, según las exigencias de cada solemnidad del año litúrgico. En el presente artículo, se entresaca de dicho "manual", todo lo que se refiere a la importante participación musical en cada una de dichas solemnidades.

\section{Introducció-Premisses}

Tot treballant en les meves investigacions musicals, principalment en l'obra del gran teòric i compositor Francesc Valls, mestre que fou de la catedral de Barcelona, des de l'any 1696 fins a la seva mort, ocorreguda el 1747, en les diferents etapes de coadjutor i titular fins al 1726 i jubilat, després, em vaig interessar també per l'estructura que vertebrava l'activitat musical dels compositors de la nostra seu barcelonina, això és, la raó dels títols de llurs composicions i, per tant, les festes que s'hi celebraven, llur solemnitat o categoria litúrgica, etc. Sortosament, vaig trobar l'eina que me n'oferia la solució, a l'arxiu de la susdita catedral. 
Efectivament, a l'arxiu de la catedral de Barcelona, es troba un manuscrit, que duu al llom els títols de "Cabiscol" i/o també "Manual del Cabiscol", el qual citaré normalment com el "Manual". A la coberta, escrit en llàpis, hom llegeix "1682-1729”. Cal remarcar que el darrer document porta, efectivament, la data tres d'agost de 1729, si bé el cos principal podria haver estat redactat, fins i tot, abans de finir el segle disset. I, comparant aquestes dates amb les del magisteri de Francesc Valls, hom dedueix que el magisteri d'aquest s'escau plenament dins del període de confecció i de més vigència del nostre manuscrit, el qual té 184 folis numerats.

Es tracta, doncs, del manual o consueta, que recull la normativa de totes les celebracions litúrgiques que tenien lloc durant tot l'any, normativa acumulada per tradició al llarg de generacions i assigna a cada festa la música que li corresponia, la qual, si no es diu el contrari, s'ha d'entendre que es tracta del cant pla/gregorià. L'enunciat del capítol quart dóna la raó d'aquesta recopilació, tot dient: "de las ordinations antigas y renovadas en los Capitols generals del Any $1682 "$.

El contingut del manuscrit s'expressa a l'índex que hi ha al principi, el qual transcric paleogràficament a continuació:

"Taula del contengut en lo present llibre, o, Manual

Capitol pr. del offici y obligations del Cabiscol de la Seu de Barna. fol. 1

Capitol 2. del offici y obligations del Succentor de dita Igla. fol. 4

Cap. 3. de algunas advertensias acercà del referit en los dos capitols antecedents. fol. $\quad 5$

Copia sententiæ in causa Precentoris et Succentoris Cathedralis Ecclæ. Barcinonen contra ipsam Ecclesiam fol. $\quad 6$

Cap. 4. de las ordinations antigas y renovadas en los Capitols generals del Any 1682. fol. 11

Cap. 5. de algunas advertensias a cerca del peculiar modo de officiar de nra.

Igla. Cathedral de Barna. fol.

Cap. 6. de Las Matines Cantadas ab solemnitat fol. $\quad 21$

Cap. 7. del Doble Major de primera classe f. 26

Cap. 8 del Doble Major de 2a classe. fol $\quad 37$

Capitol. 9 del Doble Major p. Annum fol. $\quad 39$

Cap. 10. del Doble menor p. annum. fol. $\quad 41$

Cap. 11. del Semidoble fol. $\quad 46$

Cap. 12 del Simple o ferial. $\quad 48$

Cap. 13. dels Aniversaris. fol.

Chalendari de tots los mesos y dias del Any en que etc. Cap. 14 fol. 55

Cap. 15. del modo de officiar en las Dominicas de Advent, Septuagesima, Sexagesima y

Quinquagesima fentse lo offici del temps. fol. $\quad 99$

Cap. 16. de las Ferias $4^{\mathrm{a}}$.- $5^{\mathrm{a}}$. y $6^{\mathrm{a}}$ Cinerum 101

Cap. 17. De las Dominicas de Quaresma fol. 102

$\begin{array}{ll}\text { Cap. 18. de las ferias de quaresma. fol. } & 103\end{array}$ 
Cap. 19. de La Semmana de Passio fol. $\quad 104$

Cap. 20. de la Dominica Palmarum y Semmana Santa fol. 105

Cap. 21. de la Domca. de Pascua Resurrectionis, y dels dias seguents fins a la

$\begin{array}{ll}\text { Dominica in albis inclusive fol. } & 111\end{array}$

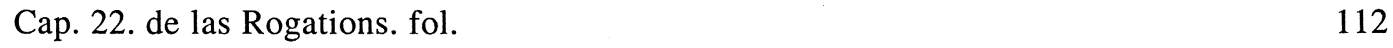

Cap. 23. de la Ascensio y Pentecostes. fol. 117

$\begin{array}{lr}\text { Cap. 24. de la vigilia, dia y octava de Corpus f. } & 119\end{array}$

Cap. 25. de las Dominicas p. annum. fol. 126

Cap. 26. de la hora que se acostuma entrar als officis en nostra Igla. en tot lo temps del $\begin{array}{ll}\text { any. fol. } & 127\end{array}$

Cap. 27. dels 3 Aniversaris se acostuman fer los 3 dias de Carnestoltas per la Ciutat. fol. 133

$\begin{array}{ll}\text { Combregar de Bisbe fol. } & 134\end{array}$

$\begin{array}{ll}\text { Cap. 28. de las Sepulturas de Bisbes fol. } & 135\end{array}$

Cap. 29. de las Sepulturas Canonicals p. Canonges. fol. 139

Exemplar de dos Sepulturas de dos Canges. en lo dia de St. March y assertantse en la Domca. in albis y que la Professo havia de anar al Hospital. fol. 141

$\begin{array}{ll}\text { Exemplar de Pregarias p. Pluja fol. } & 145\end{array}$

Exemplar de Pregarias p. lo bon succes del siti de Viena fol. 156

Actio de gratias p. la victoria obtinguda en dit siti 157

Exemplar de Pregarias p. lo bon succes de la guerra contra fransa. fol. 158, 171

Actio de gratias p. la victoria obtinguda dels francesos en lo siti de Girona $\quad 159$

$\begin{array}{lr}\text { Exemplar de entredit fol. } & 160\end{array}$

Exemplar de Pregarias p la plaga de la llagosta fol. $\quad$ 164-167

Exemplar de funerarias p la Reyna de Espa $\quad 169$

$\begin{array}{ll}\text { Tedeum } p \text { lo feliz arribo de la Reyna nova esposa } & 175\end{array}$

$\begin{array}{ll}\text { Combrega y enterro de un escola de grana } & 168\end{array}$

Exemplar de Pregarias p ocasio de la malaltia del Rey. y Actio de gratias p la millora 176

Exemplar de Conbregar y mort del Archabisbe de Tarragona, fol. $177 \mathrm{v}$

Mort del emperador Joseph (hi ha un mot que no interpreto a la fotoc.) 178

Aquest índex l'agrupo d'acord amb la temàtica que m'assembla més adient entre ells, per tal d'oferir una visió més sintètica del contingut del manuscrit. Així, doncs, considero les:

Premisses: Dignitats de cant (caps. 1r, 2n i 3r), tradicions i peculiaritats (caps. 4t i 5è.

Solemnitat de les hores i festes (caps. 6è-13è).

Calendari de tot l'any (cap. 14è).

Solemnitat dels diumenges i fèries (caps. 15è-25è)

Horari coral (cap. 26).

Dins del treball, mantinc la grafia dels títols dels capítols, sense acompanyar-los de les corresponents cometes, actualitzaré, però, la dels subtítols.

Els exemplars de celebracions particulars, tant ordinàries, com extraordinàries, després del cap. 29è, apareixen sense número de capítol, potser per això, perquè només són exemplars $\mathrm{i}$ no normativa obligatòria. 
A més a més, considerant que el calendari comporta un tractament a part, el deixaré per al final de la presentació del manuscrit i el donaré en estil diferent, això és, en present, mentre que per a la resta, empraré l'estil narratiu-històric.

\section{Terminologia musical}

Els termes musicals que apareixen sovintment al llarg del treball, i per això m'abstindré de donar les referències i de posar'ho entre cometes, afecten:

a) A la classe de música: cant pla (gregorià) i cant d'orgue o figurat (polifonia). El cant d'orgue, podia ser, encara: cant d'orgue, cant d'orgue a dos cors, a tres, a quatre comptant el dels ministrils, a cant d'orgue amb ministrils, sense ministrils, a cant d'orgue a quatre cors, a dos cors a cant figurat

b) A la manera de cantar i a allò que es cantava, com en els: dobles majors i/o com els dobles menors, matines cantades amb molta solemnitat, alternant tot el cor amb l'orgue, els dos cors alternant sense l'orgue, havent-hi orgue i sense haver-hi orgue, Credo alternant un vers a cant figurat i un altre tot el cor a cant pla, Salve resada o cantada, salm In exitu Israel pel to setè, salm Ad te Dne. levavi... pel to setè, alternant un vers a cant pla per tot el clergat amb un altre a fals bordó pels cantors, Tantum ergo a fals bordó, tot cantat i/o tot resat, absoltes a cant d'orgue (tota a cant d'orgue) i absoltes a cant d'orgue i cant pla, motet, villancico, siesta, cantar "submissa voce", "aliquantulum submissa voce", un "Credo de la monja" (pg. 37), del qual no n'he trobat menció a d'altre lloc.

\section{Dignitats de cant}

Del títol del manuscrit, hom s'adona que l'ofici del capiscol ${ }^{1}$ (cap. 1r), dignitat capitular, que tenia la residència i seient al cor de Sant Joan, immediatement després de la cadira de l'ardiaca major, era

"provehir y disposar acerca dels officis y exerçiçis que han de fer tots els Canonges y Beneficiats, Capellanius y Conductius de dita Iglesia Segons fou ordenat per lo Ilm. y Revdm. Sr. D. Joan Bisbe Savinense Llegat per la Seu Apostolica en lo Any 1229. y tambe entonar a Matines tercia y vespres de tots los dobles majors...".

Tot seguit, fa la història de la configuració progressiva de les obligacions d'aquesta dignitat i de la del succentor, segons les actes capitulars, perquè altra dignitat capitular de cant, de la qual en parla el manuscrit, és la del succentor (cap. 2n.). Aquest tenia obligacions i responsabilitats semblants a les del capiscol, no endebades se l'obligava a fer "continua residentia" en el

1. Sobre les Dignitats i Oficis de cant, a la nostra catedral, podeu consultar: Pavia i Simó, J., La música a la catedral de Barcelona durant el segle XVII, Fundació Salvador Vives Casajuana, Barcelona, 1986, cap. II i III, pp. 45ss. 
cor i suplir en tot al capiscol, en les absències d'aquest i, en aquest mateix Manual, hom l'anomena indistintament succentor i capiscol (foli 26):

"Los dits Cabiscols (o, lo Cabiscol y Succentor que es lo mateix, axi que sempre q direm, los Cabiscols se ha de entendre lo Cabiscol y Succentor)...".

\section{Tradicions i peculiaritats}

El manuscrit, que respon a la decisió capitular (Capítols Generals del 1682, com s'ha dit) de recollir, renovades, les ordinacions antigues, regula i sintetitza (cap. 4), en 18 articles, tot el que concernia a la presència i comportament dins del cor, per part de tots els qui tenien l'obligació d'assistir-hi i també adverteix de la manera peculiar d'oficiar de la nostra Seu (cap. 5è). D'aquest capítol cinquè, considero molt important donar-ne un resum, perquè presenta els escenaris cor-altar, amb la interrelació existent entre aquests dos punts, on es desenvolupa la pregària de les hores (cor) i l'acció eucarística (altar), amb els ministres actuants. El manuscrit redueix a set aquests avisos previs:

1r. Després de recordar les diferents solemnitats que valen per a l'Església universal, remarca que

"sols es lo intent tractar assi del peculiar modo de officiar, o, de la solemnitat y serimonias particulars que se observan en ella, en dita Igla. En totas las festivitats del any".

2n. Explica la distribució del cor:

“... en dita Iglesia lo Cor se divideix en dos parts, de las quals la de ma dreta [enteneu mirant a l'altar] se diu lo Cor de S, Joan, y la altra lo Cor de S. Pera. En cada un destos dos Cors hi ha Dos Domers Canonges, que vulgarment se diuen Domers Majors, als quals toca una semana a cada un fer la doma en las primeras y segones vespres de tots los Dobles majors, y en las Matines quant se diuen cantades; en lo demes toca a fer la doma als dos Domers menors, o, Conductitios, que hi ha tambe en cada Cor a mes dels dos sobredits Canonges".

3r. La dignitat de capiscol era al cor de Sant Joan, i la dignitat de succentor al de Sant Pere. També hi havia, a cada cor,

"un entonador menor conductitio que vulgarment se diu Dormitorer, y al qual toca entonar en totas las functions en las quals no offitian los sobre dits Cabiscol y Succentor"

4t. A cada cor, hi havia dotze canonges, quatre dels quals eren preveres, quatre diaques i quatre sotsdiaques. Així mateix remarca que els dos domers majors eren preveres. Al cor de Sant Joan, hi havia un beneficiat anomenat "Diaconil" i al de Sant Pere un altre, anomenat "Subdiaconil", normalitzats com: Diaconal i Subdiaconal.Totes aquestes dignitats i oficis tenien establertes, subsidiàriament, de major a menor, llurs tasques musicals. 
5è. De l'altar major es diu:

“... en lo Altar major de dita Igla. Ningun dia se diu sino una Missa tant solament que es lo offici major o conventual, y esta sempre la ha de dir un Canonge...; Sols lo dia de Nadal a mes del offici major se diu tambe en dit Altar la Missa del Gall".

Si hi havia d'altres misses, es celebraven a l'altar de Santa Eulàlia.

6è. No obstant que el cor de Sant Joan era el principal, per trobar-s'hi la seu del bisbe, en el manuscrit s'anomena «major» al cor, on és la doma, alternant per setmanes i «menor»a l'altre.

7è. Declara que, a la Seu barcelonina, la solemnitat de les festes, tant les de l'Església universal, com les locals, no coincidia sempre forçosament amb la norma general.

Abans de concloure el capítol, es fa notar que:

"encara que en temps passat [les matines] se deyan tots los dias totes cantades; ara de algun temps a esta part se diuen casi tots los dias resades fins al Tedeum exclusive, exceptats alguns dias, que ja se notaran en son lloch y temps, en que se diuen totes resades y altres en que se diuen totes cantades y quant se diran cantadas totas, de ordinari se diuen a la tarda immediatament acabadas completes (menos lo dia de Nadal que se comensan al punt de la mitja nit) ab molta solemnitat y seremonias de las quals se tracta en lo capitol seguent".

De tota aquesta reglamentació, n'extreuré tot allò que pertany a l'activitat musical, amb els detalls imprescindibles de la part ritual que l'acompanyava i deixaré la part estrictament cerimonial. D'altra banda, el coneixement de les festes, amb la categoria litúrgica que tenien, ajudarà a entendre millor el perquè de les composicions musicals i també la diferència quantitativa i qualitativa d'aqueixes, com també les hores de cultura musical que la catedral oferia diariament a la societat, a travès del seu culte.

\section{Categories litúrgiques i solemnitat}

\section{Solemnitat i categoria de les hores i festes}

Tothom coneix les diferents solemnitats o "classes" litúrgiques amb què l'Església valora o classifica les seves festivitats. El nostre "Manual del Cabiscol" recull les següents, que eren vigents aleshores: Doble Major de primera classe (aquests, solen tenir octava), Doble Major de $2^{a}$ classe (també n'hi ha amb octava), Doble Major per Annum, Doble menor per annum, Semidoble, Simple o ferial i Aniversaris, les quals estudia una a una. També tractarà de forma especial les festes més importants i els diumenges dels diferents temps litúrgics. La diferent solemnitat de les hores, n'és una consequiència lògica de la solemnitat del dia.

En el present capítol, es descriu la solemnitat de les matines i de les laudes. 
De les matines cantades amb solemnitat (Cap. 6, f. $21 \mathrm{v}-24 \mathrm{v}$ )

En aquestes matines, feia la doma el domer major. Els sacristans repartien dotze ciris encesos fabricats expressament per a la funció de cantar l'invitatori, a les dignitats i canonges, els quals es posaven en dues fileres al costat del faristol ${ }^{2}$ col-locat al fons del cor. El domer deia «submissa voce»: Domine labia... i els dos dormitorers, des del faristol, on eren juntament amb els dels ciris encesos, entonaven, «submissa voce» també, l'invitatori, que era repetit pels capiscols, els quals estaven, revestits amb capa, però sense bordons, al faristol major, on havien d'ésser també els domers menors. Repetit l'invitatori, els dos canonges més joves, dels qui tenien el ciri encès del cor que presidia, anaven al faristol i cantaven el primer verset del Venite exultemus..., finit el qual, s'en tornaven al seu lloc. Els capiscols i domers susdits repetien l'invitatori, en el mateix to que s'havia cantat el verset, si bé, aquest s'entonava cada vegada més alt. El segon vers era cantat pels dos canonges més joves de l'altre cor, de la mateixa manera que el primer. I així successivament, alternant. Al final deixaven els ciris i se n'anaven, cadascú al seu seient.

L'himne era cantat o bé a cant d'orgue, o bé alternant tot el cor amb l'orgue, com es dirà, en tractar de les vespres del doble major. Les antífones dels tres nocturns, les entonaven dignitats o canonges de cada cor, invitats alternativament pel capiscol. El canonge que havia estat invitat per a l'antífona, entonava, ell sol, el salm corresponent. Els versets dels nocturns corresponien als escolans de cota de grana, els quals els cantaven davant del faristol major, a la part de l'altar major. Les absolucions i benediccions, les cantava el domer sol. Les lliçons, les encarregava el succentor, d'acord amb un orde establert i s'havien de cantar des de la «Troneta», on també havia de ser-hi el mestre d'accent, per tal de corregir les possibles faltes d'accent. Quant als responsoris, es detalla qui els cantava, invitat pels «Cabiscols», o capiscol i succentor. Quan els responsoris, però, eren cantats a cant d'orgue, no s'invitava ningú. El Te Deum, quan no era cantat a cảnt d'orgue, l'entonaven els capiscols agenollats.

\section{"Laudes" solemnes f. $24 \mathrm{v}-25 \mathrm{v}$}

Els capiscols també invitaven per entonar antífones i salms, com s'ha dit a les matines i laudes. La capítula era cantada pel domer sol. L'himne el cantava tot el cor, alternant amb l'orgue. Els versets corresponien als escolans, com a matines. L'antífona del Benedictus la preintonava el capiscol del cor que presideia al domer, el qual l'entonava tot sol, el Benedictus, però, era cantat per tot el cor, alternant, però, amb l'orgue, el qual comensava i acabava. La col·lecta la deia el domer des del faristol major, el Benedicamus, però, el deia «tot lo conjunt» i responia l'orgue. El domer, «submissa voce», deia el Fidelium anima... La Salve, aquests dies solemnes, es deia ordinariament a cant d'orgue $i$, finida la qual, s'en tornaven a la sagristia, seguint l'ordre establert.

2. El faristol és un punt preeminent, sobre tot dins del cor. Ara bé, s'evidencia, a diferents indrets del manuscrit, que hi havia diferents faristols, dins del cor. 
Es posa de relleu, al final del capítol, que, quan s'havien anticipat les matines a la tarda anterior, tan sols es deia l'hora de prima, la qual solia ser resada, per manca de residents. Llavors, feia la doma el domer menor i oficiava el dormitorer, no els capiscols.

\section{Del Doble Major de Primera classe (Cap. 7: f. 26-28v)}

\section{De les primeres vespres}

- Quant a les entonacions de les antífones, salms i demés i a la incensació, etc. es procedia, més o menys, com s'ha dit de les matines i laudes, en el capítol anterior.

- Hom hi troba també el ritual de la visita o estació que es fa a les capelles, finida aquesta hora, en determinades festivitats, en la qual estació s'empra incens, es diu una oració i

«cantant los dormitorers y Domers menors uns versets que estan ja assenyalats per cada festa en particular en uns llibrets ${ }^{3}$ que hi ha aposta per axo y per les professons que ordinariament se fan per la Iglesia».

\section{De les Completes (f. 29-29v)}

L'entonació de les diferents parts es feia de la manera següent: El dormitorer del cor que presidia, havia de convidar un dels canonges més antics del susdit cor per cantar el Jube Domne.

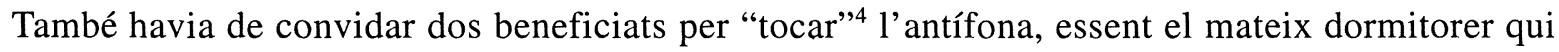
entonava el salm, l'himne i el Nunc dimittis. La capítula era cantada pel domer i els versets per dos canonges dels més antics, un de cada cor, els quals també entonaven el Benedicamus Domino. L'antífona Salva nos era entonada pel domer, al qual la preintonava el dormitorer, qui també entonava la Salve.

Es contempla la celebració anticipada de les matines, tot seguit de les completes i, a més, la presència del bisbe, amb la part que li corresponia, com a cap del capítol.

\section{De les Matines (f. 30-31)}

El Manual fa distinció entre les matines cantades amb solemnitat, com s'ha dit més amunt, les quals s'anticipaven a la vigília i eren totes cantades, i les que es deien resades fins al Te Deum. Aquestes, tant en els dobles majors de primera i segona classe, com en els dobles tualitat.

3. Sense cap mena de dubte, es deu tractar dels Processionale. Aquest ritual es conserva quasi bé idèntic, en l'ac-

4. "Tocar" o "picar" (com es diu a d'altres indrets del present treball) una antífona, consistia en entonar-la només fins a l'asterisc, abans d'entonar el salm corresponent. 
menors i semidobles, es deien a la matinada. Els dies de fèria i els diumenges, en què el rés i l'ofici era de la dominica, es deia tot resat.

Es detalla l'actuació de les diferents categories de canonges i beneficiats d'ambdòs cors en l'entonació d'antífones, salms, lliçons, etc., en el doble major de primera classe, fins a arribar al Te Deum, el qual, com s'ha dit, era cantat. L'entonaven els capiscols, agenollats davant del faristol major. El Manual fa constar anticipadament que les laudes i la prima eren cantades (amb aquest terme, enteneu sempre: a cant pla).

A laudes, es procedia com a les laudes cantades amb solemnitat, exceptuant-ne la preintonació de l'antífona del Benedictus, la qual preintonació es feia tan sols quan presidia un domer major i no, com ara, quan presidia un domer menor.

\section{Prima}

L'hora de prima també seguia la condició de les matines, si aquestes es deien a la matinada o a la vigília. En el primer cas, la prima es deia tot seguit de les laudes. Els capiscols entonaven l'himne, al tercer vers/estrofa del qual, el capiscol del cor que presidia convidava dos canonges del seu cor per entonar l'antífona, la qual entonada, ambdós capiscols entonaven el salm i, tot deixant la capa i prenent els hàbits se n'anava cadascú al seu lloc. Mentre es deia la capítula, convidaven tot el cor per anar al davant del faristol major a cantar el Christe fili, on després de dir la col-lecta, el dormitorer deia o cantava la "calenda" i el domer prosseguia la Pretiosa. La Salve era resada.

\section{Tèrcia, sexta i nona.}

Es dedueix que eren cantades i, més o menys, seguien un mateix ritual. Tanmateix, hi havia alguna particularitat en cada hora, que cal posar de relleu.

Així, doncs: feia la doma el domer menor setmaner.

A tèrcia: els dos capiscols sense capa, entonaven l'himne, el capiscol, però, del cor que presidia, convidava dos canonges del seu cor per entonar l'antífona, la qual entonada, entonaven ells, els capiscols, el salm Legem pone, i s'en pujaven cadascú a la seva cadira. Acabat el tercer salm, tornaven a baixar al faristol major per cantar l'antífona i, després, convidava cadascú un canonge dels més antics del seu cor, perquè baixessin a cantar els versets de tèrcia y el Benedicamus Dno.

A sexta i nona, era el dormitorer del cor major, el qui entonava l'himne, des del faristol de dalt, tot convidant dos beneficiats a sexta i dos doctors a nona, tots del seu cor, per entonar, respectivament, l'antífona d'aquestes hores, com a tèrcia, essent el mateix dormitorer tot sol, qui, des del faristol de dalt, situat davant del domer, entonava els salms Defecit i Mirabilia. A més a més, convidava, a sexta, un beneficiat dels més antics de cada cor, perquè anessin al faristol major a cantar els versets i el Benedicamus Dno. A nona, en canvi, corresponia fer aquestes funcions a un doctor de cada cor. 
Acabades aquestes hores, es deien resades les lletanies, les quals deia el domer tot sol agenollat davant del faristol major i responien tots, agenollats cadascú al seu lloc.

\section{De la processó i ofici (f. $32 \mathrm{v}-36 \mathrm{v})$}

Processó. Acabades les lletanies, s'iniciava una processó que sortia per la porta del cor "que mira al portal major" i, després que "roda tota la Iglesia", "torna a entrar per la mateixa porta". Durant la processó, els dormitorers i domers menors havien de cantar els versets o responsoris assenyalats per a cada diada en uns llibrets "fets aposta per axo". També es feien quatre estacions, això és, $1^{\mathrm{a}}$ a Sant Marc, $2^{\mathrm{a}}$ a la capella dels Sants Innocents, $3^{\mathrm{a}}$ davant de la porta de la sagristia i $4^{\text {a }}$ davant de la porta del cor. En totes quatre, eren convidats diferents capitulars per ajudar a cantar els versets o responsoris, tot pujant de categoria fins a arribar a "la dignitat mes preheminent per la $4^{\mathrm{a}}$ y ultima estacio". El cerimonial estableix al detall com s'havia de fer, on i com s'havien de situar, etc., detalls que m'estalvio per raó d'espai. Quan el bisbe era al cor, també anava a la processó, amb el gremial.

Ofici. Tornada la processó al cor, s'iniciava l'ofici, amb la solemnitat que es descriu al Manual. Cal remarcar que els capiscols deixaven la capa i bordons i invitaven una dignitat de cada cor a prendre-la per a l'ofici. Igualment la conservaven durant tot l'ofici els dos canonges que l'havien tinguda durant la processó i també prenien capa i bordó els dos doctors que havien estat convidats per cantar els versets de la nona i els dos beneficiats convidats per als versets de sexta. A més, en dir-se el primer Christe eleison, les dos dignitats i els dos canonges que duien capa, anaven del cor a l'altar major per entonar el Gloria in excelsis al "missa cantant".

L'epístola era cantada pel sotsdiaca al cor, al faristol major. Entrava al cor i en sortia per la porta que mira a l'altar major. Era acompanyat pel diaconal i el subdiaconal, els quals en tenien obligació per raó de llur benifet, així com també havien d'acompanyar el diaca quan havia de cantar l'evangeli, i quan anava a incensar el cor o a donar la pau. Si el bisbe era al cor, el sotsdiaca li havia de besar la ma, abans i després de cantar l'epístola.

El gradual, quan no era cantat a cant d'orgue, el cantaven una dignitat, un canonge, un doctor i un beneficiat de cada cor, invitats pels beneficiats que portaven la capa (v. infra cap. 10 \& 7).

L'evangeli era cantat a la trona major pel diaca, el qual, quan el bisbe hi era present, anava a demanar-li la benedicció. El diaca entrava al cor per la porta que mira a l'altar major i en sortia per la que mira al portal major, a la qual tornava després de cantat l'evangeli i s'hi quedava, mentre es deia el Credo, fins a l'Et incarnatus est. Aleshores, mentre el bisbe estava agenollat, li presentava el missal perquè hi fes l'òscul i se'n tornava a l'altar per la porta que hi mira.

El Communio (el Manual diu: "lo post Comunio") l'havien de cantar tots els que duien capa, ajudats, però, pels dormitorers.

A les segones vespres i completes, es procedia com a les primeres, llevat d'algun detall de molt poc relleu. 


\section{Del Doble Major de $2^{\mathrm{a}}$ classe (Cap. 8 , f. 37)}

En el doble major de segona classe, s'oficiava com s'ha dit abans del doble major de primera classe, amb la petita diferència que, en aquell, els capiscols convidaven dos canonges dels més joves per cantar els versets de tèrcia, mentre que en aquest, convidaven els més vells. També hi havia alguna petita diferència en el parament de l'altar. Tanmateix, el propi Manual reconeix que aquests dobles de primera i segona classe, ordinàriament eren coneguts senzillament com dobles, sense fer diferència, quant al nom, entre ells, encara que en les cerimònies se'n feia, com s'ha demostrat.

A tèrcia, oficiava el domer menor. A sexta i nona, el dormitorer del cor que presidia. A les segones vespres, els capiscols havien de convidar, per prendre la capa i el bordó i, per ajudarlos a entonar, el canonge més antic, després d'aquell que havia estat convidat per fer-ho a les primeres vespres.

\section{Del Doble major per annum Cap. 9, f. 39}

Al Manual, s’adverteix, en aquest capítol, que

"diem assi doble major per annum tant solament per explicar la differentia que se fa en nra Igla en lo modo de officiar ademes de las dos sobreditas, y no per que las festivitats de que ara parlarem la universal Igla. las fasse dobles majors per annu[m]; Per que lo modo de officiar de que ara discorrerem se observa ordinariament en las festivitats dels apostols, a las quals la universal Igla fa dobles de $2^{a}$ classe, pero per que nra Igla celebra ditas festivitats dels Apostols ab menor solemnitat que lo doble major de $2^{a}$ classe que queda referit en lo cap. 8. immediatam.t antecedent, per so ara en tercer lloch diem doble major $\mathrm{p}$ annu[m]".

1. Les primeres vespres. Hom s'adona de seguida de les diferències que hi havia, quant a la solemnitat, entre les primeres vespres dels dobles majors de primera i segona classe, les quals eren aquestes: tenien capa i bordó els capiscols, els quals havien de convidar per a les antífones, com s'ha dit dels dobles anteriors, i cada un dels capiscols havia d'entonar el salm que li corresponia, tot sol. L'himne i el Magnificat eren cantats per tot el cor alternant amb l'orgue. Els versets de després de l'himne eren cantats pels escolans, "more solito" i l'antífona del Magnificat l'entonava el domer, sense que ningú la hi "preintone".

Si hi havia estació després de vespres, els capiscols invitaven tan sols un canonge, el més jove de cada cor,

"per tenirlos lo bordo, y ajudar a cantar lo respons, o, vers que se diu en lo altar haont se fa la estatio".

2. Les Completes. El dormitorer del cor major havia de convidar un doctor pel Jube Domne, i dos doctors del mateix cor per entonar l'antífona Miserere i ell havia d'entonar el salm, 
l'himne Nunc dimitis i la Salve. Per als versets In manus, però, havia de convidar dos doctors, un de cada cor.

3. A Matines, laudes i prima, s'oficiava en tot, com s'ha dit en els dobles majors de segona classe. Però per als versets de prima, no baixaven tots davant del faristol major, sinó que el susdit dormitorer convidava dos beneficiats per fer-ho.

4. Les hores de tèrcia, sexta i nona. La diferència amb el doble major de segona classe rau en el fet que, en el doble major "per annum", el capiscol del cor major convidava dos canonges del seu cor per entonar l'antífona, però per entonar els versets, cada capiscol invitava un canonge dels joves del seu cor.

A sexta, el dormitorer convidava dos beneficiats del cor que presidia per a l'antífona i altres dos, un, però, de cada cor, per als versets. A nona, l'antífona era entonada per dos doctors $\mathrm{i}$ els versets per altres dos doctors.

5. Processó i ofici. A la processó, es procedia com s'ha dit del doble major de segona classe, tan sols que només portaven capa els capiscols. A l'ofici, però, n'hi havia quatre, de capes, les quals eren portades pels dos canonges que havien estat convidats per cantar els versets de tèrcia i els dos beneficiats convidats per als versets de sexta. En aquestes festivitats, l'ofici ordinariament es cantava a cant pla.

A les segones vespres $i$ completes, s'oficiava en tot, com a les primeres.

Del Doble menor per annum Cap. 10, f. 41

\section{Primeres vespres, f. 41}

Feia la doma el domer menor setmaner. Dos escolans de cota de grana ${ }^{5}$ entonaven les antífones, cada una des de diferents punts del cor, la primera, però, davant del faristol major, la qual antífona proseguia tot el cor junt. Els salms eren entonats pel dormitorer del cor que presidia. Mentre el domer incensava l'altar major, acompanyat de dos escolans de cota morada, el cor cantava l'himne, alternant amb l'orgue. Els escolans de cota de grana cantaven el vers de després de l'himne. El dormitorer "preintona" l'antífona del Magnificat al domer, el qual l'entonava, i, tot seguit de l'antífona, que havia de continuar tot el cor, l'orgue començava el susdit càntic del Magnificat, que proseguia alternativament tot el cor. Després que el domer deia la col·lecta, tot el cor deia (cantat?) el Benedicamus Domino, el qual era respost per l'orgue, ritual aquest que, segons el Manual, es feia d'aquesta manera sempre que hi havia orgue. Acabava el domer, dient el Fidelium anima, etc. i se n'anava a la sagristia a deixar la capa, excepte quant hi havia estació, per a la qual el dormitorer convidava dos canonges joves, ordenats "in sacris", un de cada cor, els quals havien de cantar els versets o responsori de l'estació.

5. Sobre els escolans de cota de grana i els de cota morada, v. J. Pavia, La música a la catedral de Barcelona durant el segle XVII, Fundació Salvador Vives i Casajuana, Barcelona, 1986, pp. 115-167 i el mateix autor: "La capella de música de la Seu de Barcelona des de l'inici del segle XVIII fins a la jubilació del mestre Francesc Valls $(14-3-1726)$, AnM, 54 (1990), pp.17-66. 
2. Completes. f. $42 \mathrm{v}$

Donat que el domer que havia presidit vespres, era a la sagristia a deixar la capa, començava completes un altre domer i, si no n'hi havia cap, les començava el dormitorer fins a tant no tornava el domer de la sagristia, per tal que el cor no parés el temps que aquest trigava a tornar de la sagristia.

L'entonació de les diferents parts es feia de la manera següent: Un doctor invitat pel dormitorer deia el Jube domne, mentre que l'antífona era entonada per dos escolans de grana i el dormitorer entonava el salm i l'himne, durant el cant del qual, es convidava un doctor de cada cor per cantar els versets In manus tuas i el Benedicamus Domino. El domer entonava l'antífona del càntic Nunc dimittis, havent-la-hi "preintonada" el dormitorer, el qual al seu torn, entonava el susdit cántic i la Salve.

\section{Matines. f. 43}

Es procedia com s'ha dit al capítol 7, § 3. Al final, el dormitorer, agenollat davant del faristol major, entonava tot sol el Te Deum, que era continuat alternativament, per tot el cor i l'orgue.

\section{Laudes. f. 43}

Finit el Te Deum, entraven al cor els dos escolans de grana setmaners i entonaven les antífones de la mateixa manera com s'ha dit a les primeres vespres i el dormitorer entonava igualment els salms. El domer entonava l'antífona del Benedictus, havent-la-hi "preintonada" el dormitorer, i la col·lecta. El dormitorer, al seu torn, havia d'entonar el cántic, encara que no es fa constar. L'himne i el Benedictus, es deia alternant tot el cor i l'orgue. El Benedicamus Domino, però, el deia tot el cor junt i responia l'orgue.

\section{Prima. f. 44}

L'himne era entonat pel dormitorer i l'antífona pels escolans. El salm l'entonava també el dormitorer, el qual, mentre es deia el tercer salm, convidava un doctor de cada cor per cantar els versets. Després, ell cantava la calenda, des del faristol major estant i, a son temps, cantava la lliçó breu. La Salve era resada.

\section{Tèrcia, sexta i nona. f. 44}

Sempre feia la doma el domer menor. El dormitorer entonava els himnes i els salms i, mentre es deia el tercer salm, convidava un beneficiat de cada cor per cantar els versets i Bene- 
dicamus Domino. A nona, però, havien de ser doctors. Dos escolans de grana entonaven les antífones $\mathrm{i}$, immediatament després de nona, es deia la lletania resada.

\section{Ofici, o, Missa Conventual. f. 44}

L'ofici començava tot seguit de la lletania. Els capiscols convidaven un canonge de cada cor per tenir capa i entonar el Gloria al missa cantant. També havien de tenir capa els beneficiats que havien entonat els versets de tèrcia, un de cada cor, els quals, a l'ensems, havien de convidar un altre beneficiat del seu cor, perquè ajudessin a cantar el primer vers del gradual i un canonge també de cada cor, perquè ajudessin a cantar el segon vers del susdit gradual, tot seguint el cerimonial que es detalla al Manual, el qual afegeix que

"Asso se observa en tots los dobles majors de $\mathrm{p}^{\mathrm{a}}$. y $2^{\mathrm{a}}$ classe y en los dobles majors $\mathrm{p}$ annu[m] sempre que lo gradual se canta a cant pla",

amb alguna variant, quant a les preferències.

En les segones vespres $i$ completes, s'oficiava en tot, com s'ha dit de les primeres.

Del Semidoble Cap. 11, f. 46v

En general, s'oficiava com s'ha dit del doble menor, en el cap. 10. Cal remarcar, però, les següents particularitats.

\section{Primeres Vespres}

Feia la doma el domer menor setmaner i entonaven les antífones els escolans de grana, però no eren cantades per complet, sinó que només les picaven (v. nota 4). El dormitorer entonava els salms i l'himne, el qual deien els dos cors alternant sense l'orgue. Incensava el domer i entonava l'antífona del Magnificat, la qual li havia de "preintonar" el susdit dormitorer. En els sufragis, començava les antífones el dormitorer i les prosseguia tot el cor junt. Els escolans, però, deien els versets des del faristol major. Els dos beneficiats setmaners deien el Benedicamus Domino, el qual era contestat per tot el conjunt. Després, s'anava a fer l'estació, si n'hi havia i, si no, es començaven les completes.

\section{Completes. f. 47}

Un beneficiat convidat pel dormitorer, deia el Jube domne, l'antífona era entonada pels escolans i els salms i l'himne pel susdit dormitorer, el qual també s'encarregava de convidar un beneficiat de cada cor per als versets i per al Benedicamus Domino. 


\section{Matines $i$ Laudes. f. 47}

El Te Deum era entonat, a matines, pel dormitorer i era cantat sense orgue. L'himne i el Benedictus també eren cantats sense orgue i el dormitorer invitava un beneficiat de cada cor per al Benedicamus Dno.

\section{Hores $i$ ofici. f. 47}

$A 3^{a} .6^{a}$. i $9^{a}$, el dormitorer havia de convidar beneficiats, un de cada cor, diferents per a cada hora, perquè cantessin els versets i el Benedicamus Domino, A tèrcia, però, havien de ser els beneficiats setmaners, els quals havien de tenir capa en l'ofici i no entonaven el Gloria al missa cantant. Un escolà de cota morada acompanyava el sotsdiaca, tot precedint-lo, quan anava a cantar l'epístola, la qual, com s'ha dit al cap. 7, par. 5,

"sempre se canta en lo cor en lo faristol major y asso se observa tots los dias del any tant dobles majors com menors, semidobles y simples".

Per al gradual, no es convidava cap beneficiat, ja que això només es feia quan els qui tenien capa eren canonges. Al diaca, quan anava a cantar l'evangeli, el qual tots els dies de l'any es deia a la trona gran, i a incensar, també l'acompanyava un escolà de cota morada.

En les segones vespres $i$ completes, s'oficiava en tot com en les primeres.

Del simple o ferial. Cap. 12, f. $48 \mathrm{v}$

Sempre que es deia l'ofici d'algun sant, simple o ferial, es deia l'ofici "menoret" de Nra. Sra., tot resat. Les matines ja sabem que eren resades i, pel que fa a les laudes i prima, es diu que "seguidament [de les mateines] se diuen Laudes y Prima tot resat".

La tèrcia era cantada, tot entonant l'antífona els escolans i el salm el dormitorer, el qual també cantava tot sol els versets des del faristol de més avall, dels tres que hi havia a les cadires de dalt i responia tot el cor junt. Els versets de les tres hores, els havia de cantar tots els dies ferials el beneficiat setmaner del cor que presidia, però — reconeix el Manual-

"com de ordinari ni ha pochs que los sapian cantar conforme se deu, ho acostuma fer casi sempre lo Dormitorer".

El domer baixava al faristol major, on deia la col·lecta i els escolans estant darrera d'ell, deien el Benedicamus Domino. Tot seguit es deia la tèrcia de l'ofici "menoret", resada.

Sexta $i$ nona es deien com la tèrcia $\mathrm{i}$, després de cada una es deia, també, l'hora corresponent del "menoret". Després, deien la lletania. 
Josep PAVIA I Simó

En aquestes diades s'acostumava a dir aniversari — de què en parlaré més endavant-, exceptuat quan es tractava de fèria privilegiada.

Quan es celebrava de Sancta Maria in Sabbato, es deien les laudes, prima, tèrcia, sexta i nona cantades, com en els semidobles.

Dels Anniversaris Cap. 13, f. 51

D’acord amb el Manual,

"En nostra Iglesia se fan dos maneras de Aniversaris, uns que se diuen Beneficials y altres Canonicals".

Els aniversaris beneficials, ordinàriament, eren de requiem. Els celebrava sempre el canonge prevere setmaner $i$ el diaconal i el subdiaconal feien de diaca i sotsdiaca, respectivament. Dos beneficiats, un de cada cor, havien de tenir capa i bordó, els quals havien de fer la mateixa funció que feien els capiscols, com més avant es dirà.

En els aniversaris canonicals, també presidia el canonge prevere setmaner, però feien de diaca i sotsdiaca els canonges setmaners, i, en el cor, tenien capa i bordó els capiscols. D'aquests aniversaris, n'hi havia de dues classes: els aniversaris amb solemnitat i els de requiem.

Els Aniversaris amb solemnitat eren aquells que es celebraven en dia de doble, o en dissabte, quan l'ofici era de Sancta Maria in Sabbato, o d'infraoctava de Nostra Senyora. S'oficiava de la mateixa manera com s'ha dit del doble menor (cap. 10, \&7, f. 45). Els capiscols, un cop acabada la missa, restaven al cor, per fer les absoltes corresponents, per raó de l'aniversari.

Els aniversaris de requiem, eren aquells, en els quals es deia la missa de requiem. Aquests aniversaris eren cantats, o bé "a cant figurat" - enteneu a cant d'orgue, com dirà el mateix Manual unes ratlles més endavant-, o bé a cant pla.

Quan eren cantats a cant figurat, els capiscols no cantaven, perquè ja cantava el cor dels músics. El tractus Absolve Domine i els dos versets que el segueixen, eren cantats per tot el cor junt a cant pla, fins i tot quan es cantava a cant figurat, entonats, però, pels capiscols. També era costum de cantar a cant pla la seqüència, tot alternant els dos cors, començant, però, pel cor menor. Per a aquest acte, havia de sortir tot el "clero" davant del faristol major, exceptuant-ne el canonge més antic, el qual restava en sa cadira, com a president. També estava previst el ritual propi, en aquells casos, en què la Sequentia era cantada a cant d'orgue. Acabada la missa, els capiscols anaven a la part del faristol que mira a l'altar major, per començar les absoltes corresponents.

Quan es cantava a cant pla, els capiscols, ambdós junts i sols, davant del faristol major, havien de cantar les següents parts de l'introit: Requiem aternam, Te decet hymnus Deus in Sion i altre cop el Requiem aternam. La resta de l'introit era cantada per tot el cor alhora. El capiscol del cor major entonava el primer Kyrie, cantant la resta, tot alternant, els dos cors. Per als gra- 
dual i tractus, els susdits capiscols entonaven les paraules següents: Requiem aeternam, In memoria aterna, Absolve Dne., Et gratia tua illis succurrente, Et lucis aterna, prosseguint la resta tot el cor junt. La seqüència era cantada com s'ha dit més amunt. A l'ofertori, els capiscols entonaven: Domine Jesu Christe i Hostias et preces, tot continuant el conjunt de residents. Quan s'havia de fer ofertori, es repartien espelmes a tots els presents en el cor, perquè a l'ofertori anessin processionalment a l'altar a ofrenar, d'acord amb el cerimonial establert i cantant l'ofertori, si és que no es cantés a cant figurat, perquè en aquest cas "ja lo canta el cor de la musica". Acabat de cantar l'ofertori, els capiscols havien de reprendre des d'Hostias et preces. Hi havia aniversaris que es deien en lloc de la missa conventual. Al Sanctus, entonaven el primer els capiscols i també el Benedictus, després de llevar Déu. També havien de dir els tres Agnus Dei, Lux perpetua i Requiem aternam $\mathrm{i}$, després de dir el diaca: requiescant in pace, iniciaven les absoltes ells sols $\mathrm{i}$ deien el primer Kyrie eleison i el requiescat in pace, al final.

Els dies ferials, a més a més de les absoltes que s'havien de fer per rahó de l'aniversari, era obligació fer-ne altres dues "de Penitentia", aixọ̀ és, la primera i la darrera, aquesta, però, havia de ser sempre Requiem aternam. En dies no ferials, tan sols se'n feia una d'aquestes, la qual era la darrera. Es fa constar que aquest ritual s'havia d'observar en tots els aniversaris, tant beneficials com canonicals. Quantes absoltes i a on s'havien de fer, ho indicava als capiscols el bosser que pagava l'aniversari.

\section{Del modo de officiar en las Dominicas de Advent, Septuagesima, Sexagesima, y Quinqua- gesima fentse lo offici del temps. Cap. 15, f. 99}

- Vespres del Dissabte: Encara que fossin de fèria, calia fer-les més pausadament que les dels altres dies.

Els escolans entonaven les antifones i el dormitorer els salms, "more solito» i, al final, tot estant darrera del faristol major, el Benedicamus Domino, al qual responia tot el cor. L'antífona del Magnificat, l'entonava el beneficiat setmaner del cor major i, després del Benedicamus Domino, el dormitorer havia d'entonar l'antífona Alma Redemptoris, durant el cant de la qual, s'anava a fer estació baix a Sta. Eulàlia, els dissabtes, però, en què l’ofici es feia «de corrent».

A Completes: Els escolans entonaven l'antífona Miserere, more solito, i cantaven els versets In manus tuas i el Benedicamus Domino. El beneficiat setmaner entonava l'antífona Salva nos.

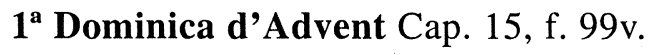

Matines, laudes i prima. En aquestes hores era tot resat, com ho era tots els diumenges de l'any.

Tèrcia, sexta i nona: 
«A $3^{\mathrm{a}} ; 6^{\mathrm{a}}$ y $9^{\mathrm{a}}$ los escolans entonan la Ana. more solito y lo Dormitorer estant en lo faristol de mes avall, que si be estos responsoris los deuria cantar de obligatio lo Beneficiat Semmaner del Cor major, com apenas hi ha ningun Beneficiat que los sapia cantar com se deu per so los acostuma cantar de ordinari lo Dormitorer. Lo Benedicamus Dno. diuen los escolans...».

Asperges. El cantava el succentor tot sol, des de la cadira, però després baixava i anava a la processó. Un cop tornat al cor, preintonava a la dignitat mes preheminent el verset o respons que s'acostumava a cantar al entrar al cor.

Introit. A l'ofici,

«lo Introit se canta a cant pla, los Kyries se cantan a cant figurat sens orga estant los Cantors a la troneta. Las respostas... a cant pla, com tambe lo gradual Ofertori y Postcomunio. Lo Credo un vers a Cant figurat y altre tot lo conjunt a cant pla. Lo Sanctus y Agnus Dei a cant figurat".

Vespres i Completes. A vespres i completes, es feia com s'ha dit del dissabte, exceptuantne l'estació a Sta. Eulàlia.

Septuagèssima Cap. 15, f. 100

Vespres. Les vespres del dissabte abans i les completes eren com les de l'advent, només que el dormitorer convidava al canonge més antic de cada cor, per dir el Benedicamus Domino, el qual cantaven tots dos, davant del faristol major. No s'anava a fer estació a Sta. Eulàlia.

Ofici. L'ofici també era com el de la primera dominica d'advent, llevat que a septuagèssima, a la processó, es feia estació davant de la capella dels Innocents o de les Ànimes i, a l'entrada del cor, no hi havia verset, sinó que el dormitorer entonava i es cantava l'antífona Veni Sponsa Christi.

\section{Sexagèssima}

Vespres. El Benedicamus Domino de vespres el deien els escolans. La resta de les hores i de l'ofici, era com a septuagèssima.

\section{Quinquagèssima}

Es feia tot com a septuagèssima i sexagèssima, excepte al entrar al cor després de la professó, moment, en què el succentor preintonava el verset, com a la primera dominica d'advent. 


\section{Del modo de dir lo Gradual y Tracte los dias de doble major o menor en lo temps de Sep- tuagesima y Quaresma. Cap. 15, f. 101}

Per al cant del gradual i del tracte, en aquestes festes, es procedia de la manera següent: Hi havia dos canonges que portaven capa i també la duien els dos beneficiats que havien dit els versets de sexta. Tots quatre iniciaven el gradual, però els canonges, en arribar al verset, s'asseien i el cantaven els beneficiats. Finit el gradual, els susdits canonges s'aixecaven i entonaven el tracte i s'asseien. El segon vers era cantat per dos canonges convidats, el tercer per dos canonges doctors convidats, el quart per dos beneficiats convidats, i també el cinquè i altres, si n'hi havia més. Convidaven els beneficiats que duien capa i ho feien en començar l'epístola. Mentre tots aquests cantaven, els que duien capa romanien asseguts. Quan es tractava de doble major, eren vuit els qui duien capa i quatre els canonges convidats.

Fèria $4^{\mathrm{a}}, 5^{\mathrm{a}}$, y $^{\mathrm{a}}$ de cendra Cap. 16, f. $101 \mathrm{v} .4^{\mathrm{a}}$

La fèria quarta de cendra. Començava el cor amb els salms responsorials, matines i laudes del minoret i, després, les matines de la fèria. Acabada la lletania, es feia la benedicció i imposició de la cendra. Durant la imposició de la cendra, els capiscols cantaven l'antífona Immutemur i Inter vestibulum amb els responsos i versos següents, ajudats d'un pabordre, un doctor, un beneficiat amb almussa i un altre sense, convidats pels susdits capiscols. Després prenien ells la cendra i cantava la clerecia.

Ofici. A l'ofici, els capiscols prenien la capa i cantaven ells sols el Gradual i el Tracte. El vers Adjuva nos el cantava

«un escola de grana, o algun official o cantor que tinga bona veu tot sol estant dret devant lo faristol major...»,

mentre tots els residents restaven agenollats.

Quant a la resta, tant d'aquesta fèria quarta, com de les dues següents, s'oficiava com s'ha dit més amunt, del simple o ferial (cap. 12, fol. 48v). La fèria sisena, però, els salms penitencials i les lletanies majors es deien després del Benedicamus de laudes, romanent tota la clerecia agenollada, "com disposa la rubrica".

El dissabte, també s'oficiava com en les fèries restants, però les vespres començaven a dir-se pel matí, fent posteriorment la corresponent estació baix a Sta. Eulàlia, tot cantant l'antífona Ave regina calorum. Noteu que aquesta estació es feia tots els dissabtes de la quaresma, com s'ha dit dels de l'advent, llevat els de passió, rams i pasqua, ja que en aquests dissabtes les vespres eren del diumenge. 
Dominiques de Quaresma Cap. 17, f. 102

S'oficiava en tot com en el primer diumenge d'advent; només que, en quaresma, quan les vespres eren del diumenge, es cantava el salm In exitu Israel a fals bordó, distribuïnt-se un sou a cada un dels canonges i cantors, i quatre diners a cada un dels beneficiats, d'acord amb una fundació feta per un tal Puigjaner.

Fèries de Quaresma Cap. 18, f. 103

En les fèries de quaresma, també s'oficiava com s'ha dit més amunt, del simple o ferial (cap. 12, fol. 48v). Però els dies en què hi havia el «velum templi», s'havia de començar l'ofici, estant abaixat el susdit "velum templi" i s'aixecava, quan el cor començava els Kyries.

Quan es feia ofici de sant semidoble, doble o infraoctava, en temps de quaresma,

"segons rubrica en las Cathedrals se han de dir dos missas cantadas, una del St. o, octava despres de tercia y altra de la feria despres de nona".

En la nostra catedral, però, la missa de fèria es celebrava a Sta. Eulàlia, mentre al cor es deien les matines. La celebrava un domer menor sol i la cantaven un sacristà menor i un beneficiat invitat pel susdit sacristà. L'ofici del corrent era celebrat a l'altar major, després de nona i de la lletania.

Els dies que només hi havia una capa al cor, era un escolà de cota de grana revestit amb alba, qui entonava el gradual, el qual prosseguien els oficials i el mateix escolà tot sol en deia el vers.

La setmana de passió o l'antecedent, es feien tres aniversaris de penitència. Els dies, en els quals es feien, s'acostumava a entrar a tèrcia a les vuit. Tots tres es deien baix a Sta. Eulàlia, després de sexta. El primer el celebrava el domer menor acompanyat dels diaconals, el capítol i el clergat, però, cantaven des del cor. Després de l'aniversari, es donava la volta a l'església i al claustre i s'anava a Montjuich, tot fent quinze absoltes, com es feia també el dia de difunts -2 de novembre-, amb la diferència que, aquesta diada, es deien tres absoltes abans de partir del cor, mentre que, els dies dels aniversaris, només se'n feia una. Només en aquest aniversari, hi tenien capa dos beneficiats. El segon aniversari també el celebrava el domer menor, però sense diaques i el capítol i la clerecia baixaven a Santa Eulàlia per cantar. Finit l'aniversari, es rodava l'església, tot fent quatre absoltes, una a cada un dels seus angles, després d'haver-ne fet una primera entre el cor i les escales de Santa Eulàlia. El tercer es feia com el segon, però, després de l'absolta entre el cor i les escales, no es rodava l'església, sinó el claustre i les quatre absoltes es feien a cada un dels seus angles. 
De la Setmana de Passió Cap. 19, f. 104

A Vespres del dissabte precedent al diumenge de passió, tenia lloc la funció de mostrar la veracreu. Ho havia de fer la dignitat més preheminent, la qual també havia de ser canonge. Deixant de banda la riquesa de detalls que acompanyaven la cerimònia, diré que, mentre la veracreu era mostrada descoberta, des del mig del presbiteri, es cantava l'estrofa $O$ Crux ave spes unica, de l'hymne Vexilla Regis. S'oficiava com en els diumenges i fèries de quaresma.

De la Dominica Palmarum i Setmana Santa Cap. 20, f. 106v-109.

Aquest diumenge, començaven les matines a l'hora acostumada i la tèrcia a les vuit. Dites les hores de tèrcia, sexta, nona i la lletania, es feia l'Asperges, i tot seguit començava la benedicció dels rams. Els capiscols convidaven un pabordre, un doctor, un beneficiat amb armussa $\mathrm{i}$ un altre sense armussa, per cantar les antífones Pueri Hebreorum, etc., com es feia el dia de cendra i el de la Purificació. La processó es feia pel claustre i, si havia fet la benedicció el bisbe, assistien els consellers, altrament no hi assistien. Quan a la pàssia, el Manual no diu com era cantada, però hom creu que, d'acord amb la tradició, es cantava a cant pla, introduïnt-hi, però, determinats passatges a cant d'orgue. El ministre que feia de diaca a l'ofici, anava a cantar-ne la part final a la trona gran. L'ofici es cantava com els restants diumenges de quaresma.

El dilluns sant, s'entrava a matines a l'hora de costum i a tèrcia a les nou. S'oficiava com a les fèries de quaresma.

El dimarts sant, s'entrava a matines a l'hora de costum i a tèrcia a les "vuit y mitja perque se canta la Passia". L'ofici era com el del dilluns.

El dimecres sant es procedia, quant a horaris, passió i ofici, com el dimarts sant. A la tarda, però, s'entrava a completes a les quatre, acabades les quals, començaven les matines del dijous "y se diuen cantadas ab molta solemnitat". Entonava els salms el dormitorer, el qual, si el bisbe es trobava al cor, el convidava a entonar la primera antífona Zelus tuus... (sic), la qual entonava el bisbe tot sol. Si no hi era el bisbe, corria a càrrec del domer que presideia. Igualment succedia amb l'antífona del Benedictus. Les restants antífones de matines i de laudes, eren entonades pels escolans de cota de grana. Era costum de cantar les tres lamentacions a cant figurat, però els responsoris es solien cantar tots a cant pla, seguint aquest ritual: el dormitorer convidava un doctor jove de cada cor per al primer responsori, un beneficiat jove per al segon, un canonge jove per al tercer, beneficiats per al quart i cinquè, un canonge per al sisè, un beneficiat per al setè, el doctor més antic per al vuitè i el beneficiat més antic per al novè "y en tots los responsoris han de ser sempre un de cada cor". Les sis lliçons darreres es cantaven a la troneta, amb aquest ordre: la quarta i la cinquena eren cantades per dos beneficiats, la sisena per un canonge, la setena per un beneficiat i la vuitena per un doctor, essent convidats tots pel dormitorer. La novena, l'havia de dir el domer que oficiava. L'oració Respice... la deia el bisbe, si era present al cor, altrament la deia el domer. 
El dijous sant a la tarda, acabades completes, començaven les matines, les quals també es deien cantades amb gran solemnitat, com el dimecres sant i observant les mateixes cerimònies.

El divendres sant, a matines, es procedia de la mateixa manera com els dies anteriors. A la processó de la santa Espina, es cantava, "submissa voce”, l'himne Vexilla Regis.

El dissabte sant, es donava un relleu especial al cant del pregó pasqual, això és, de l'Exsultet.

Es cantaven les dotze profecies, les quals tenia obligació d'encarregar el succentor a les persones que s'indiquen en el Manual.

Quant a la benedicció de les fonts baptismals, s'hi anava en processó, tot cantant dos escolans de grana el tracte: Sicut Cervus. En tornar de la benedicció, els mateixos escolans cantaven les lletanies. El cor començava els Kyries i els capiscols preintonaven el Gloria al celebrant i l'antífona del càntic Magnificat, el qual càntic era cantat a cant d'orgue.

\section{Domínica de Pasqua de Resurrecció i dies següents fins a la Domínica in albis Cap. 21, f.} $111-112$

El diumenge de pasqua era una festa de doble de primera classe, en conseqüència, a matines, laudes i prima es deia tot cantat i feia la doma el domer menor setmaner. Per al primer responsori, es convidava un doctor i per al segon el canonge més antic. L'homilia, l'havia de cantar una dignitat, la segona lliçó un doctor i la tercera el domer que feia la doma. A prima, s'havien de convidar "boni cantores" per a dir el Benedicamus Dno.

Els capiscols entonaven la tèrcia i cantaven l'antífona Hac dies. L'ofici era cantat a cant d'orgue, la seqüència, però, era cantada alternativament pel cor i l'orgue.

A vespres es cantava el Magnificat a cant d'orgue, acabades les quals, els escolans de grana entonaven l'Alleluia, que repetia dues vegades el cor. Després, els capiscols entonaven el salm Laudate pueri Dnum. pel primer to i s'iniciava una processó per anar a fer estació a la capella de las fonts, a on, un cop dita la col·lecta, els escolans tornaven a entonar l'Alleluia, el qual era repetit com abans, però els capiscols, ara, entonaven, també pel primer to, el salm In exitu i s'anava a fer estació a la capella de sant Pere.

El dilluns i el dimarts eren dobles de segona classe i l'ofici no es cantava a cant d'orgue. Els dimecres, dijous, divendres i dissabte, eren semidobles. Les laudes i la prima es deien cantades "more solito", sense orgue. A tèrcia i sexta, s'havia de convidar beneficiats per al Benedicamus Dno., a nona, però, doctors. A l'ofici, sí que hi havia orgue, per ser vuitada de pasqua.

Durant l'epístola, els beneficiats que tenien capa, amb altres dos que ells convidaven, pujaven a la troneta a cantar el gradual, acabat el primer vers del qual, hi pujaven també els dos doctors que tenien capa amb altres dos que ells convidaven, per cantar el que restava del susdit gradual i hi havien de romandre fins que fos acabada de cantar la sequiència, la qual cantaven tots els residents, havent baixat dels setials i alternant amb l'orgue. A vespres no hi havia orgue, però es feia estació a la capella del sant Sepulcre. 
El diumenge "in albis", era doble menor i es deien matines, laudes i prima tot resat. De l'ofici, no es diu res, per tant havia de seguir les normes pròpies d'aquesta categoria litúrgica, com s'ha exposat al seu lloc..

De las Rogations Cap. 22, f. 112v., 113-11

Les "rogations" o rogatives, s'esqueien en les fèries segona, tercera i quarta després del diumenge "in albis" - segon de Pasqua-, les quals, en llatí, es definien com ferice Rogationum. L'acte començava després d'haver acomplert, a la catedral, l'obligació de les hores i de l'ofici, els quals, en previsió de la subsegüent processó de rogatives, guardaven aquestes normes: Les tres fèries, s'entrava a matines a l'hora acostumada. Les matines, laudes i prima eren resades. A tèrcia s'entrava "a set horas y mitja" i tot es deia, d'acord amb la norma establerta per a la diada de sant Marc, el 25 d'abril. També la processó d'aquesta fèria començava com la del susdit dia de sant Marc. En cada una d'aquestes fèries, es feia un recorregut diferent per la Ciutat, visitant diferents esglésies i monestirs, tot sortint i acabant sempre a la catedral.

Durant la processó, es cantaven les lletanies dels Sants, les quals eren cantades cada dia per canonges diferents convidats pels capiscols i s'havien de repetir, segons la necessitat del trajecte, d'acord amb la norma del Manual. La fèria segona la lletania s'acabava al Pi, la fèria tercera a Sta. Maria del Mar i la quarta a St. Just, on es deia l'ofici, celebrat pel rector i clerecia de cada una de les susdites esglésies. D'aquest ofici, no es diu si havia de ser cantat o no, però el del dia de sant Marc, que es proposa com la norma d'aquests, era a cant d'orgue.

A cada església visitada

"mentre entra la professo dintre la Igla. los Cantors han de saludar lo Patro o Patrons de la Igla. cantant a cant de orga alguna $\mathrm{An}^{\mathrm{a}}$. de dit Patro o Patrons... los escolans diuen los versets y lo Cap de Professo diu la Colecta o Colectas. Y luego se comensan las absoltas que se han de fer dintre la Iglesia las quals han de comensar los Cabiscols menos aquellas que se cantan a cant de orga...."

Les absoltes i música que s'hi havia de fer, els llocs que es visitaven i les intencions per les quals es pregava, eren aquestes:

La fèria segona, es feien nou absoltes, segons l'ordre següent i s'aplicaven per la intenció que s'indica: església del Carme, pel Col·legi de sant Sever; església de les Caputxines, per Boxados; fossar de sant Llatzer, per la bossa comuna; església de les Gerònimes, per Boxados; església de sant Antoni, pel canonge Valeri; església de les Carmelites, pel pabordre Sebastià Grau; església de l'Hospital General, per les Ànimes; església del Pi, després de l'ofici, entre el cor i l'altar major, per la Comunitat de la susdita església; església de l'Hospital de sant Sever, una, la qual, per ser la darrera, solia ser: Requiem aternam, etc. i era per la Comuna.

La fèria tercera se'n feien catorze, en aquests llocs: església de sant Joan, per dita església; església de les Madalenes, a cant d'orgue, pel canonge Valeri; església de sant Francesc de 
Paula, pel canonge Valeri; església de sante Pere, per dita església; a sant Agustí, se'n feien tres: dues al claustre, davant de l'altar de sant Joan, pels bisbes Cassador i la tercera dins de l'església, a la capella de la Presentació pel canonge Texidor (aquesta era a cant d'orgue); església de sant Cugat, pel Col·legi de sant Sever; capella de sant Marcus, per ella i/o pel seu beneficiat; dues a l'església de santa Caterina, l'una a la capella de sant Pere Màrtir pel canonge Vilana, l'altra a la capella de santa Agnès, a cant d'orgue i cant pla, per "Petronilla Boxados"; altres dues a santa Maria del Mar, una per Miquel Ferrer de Busquets i una altra pel canonge Gualbes, a cant d'orgue, més una tercera, a cant d'orgue, al fossar, pels pares del canonge Valeri.

La fèria quarta es feien dotze absoltes, als següents llocs: església de sant Jaume, per la mare del degà Paulo del Rosso; església de sant Miquel, a on es deien dues absoltes, una per la Comuna i altra per la pròpia Comunitat de l'església; església de sant Francesc, a on es deien cinc absoltes, dues al claustre per la Comuna i tres dins de l'església: una per Novell i una altra, a cant d'orgue, per Jover Cavaller, ambdues entre el cor i el presbiteri, la tercera davant de la capella de sant Francesc, pel canonge Berenguer de Guilar; església de la Mercè, per Valeri; església de sant Sebastià, amb dues absoltes, una a cant d'orgue i cant pla, l'altra tota a cant d'orgue, essent una de les quals per la Comuna; església de sant Just, en la qual, per ser la darrera, es deia Requiem aternam etc. i era pel Col·legi de sant Sever.

Acabat l'ofici i les absoltes als susdits tres llocs, els capiscols entonaven l'antífona Regina cali i la processó iniciava la sortida. En ser als fossars de cada església, els capiscols, agenollats, entonaven l'himne Ave maris stella, mentre se'n tornaven cap a la Seu. Tornats a la Seu, entre el cor i Sta. Eulàlia es feia la conclusió, sense pujar al presbiteri.

Ascensió i Pentecosta Cap. 23, f. 117v-119.

L'Ascensió era festa de doble major de primera classe amb octava no privilegiada. S'entrava a tèrcia a nou hores i després de sexta es deia la lletania, es feia processó per l'església i després es celebrava l'ofici, acabat el qual s'exposava el Santíssim Sacrament i es cantava Tantum ergo a fals bordó, i tot seguit començava la nona, amb el següent ritual: El domer del presbiteri, entonava el Deus in adjutorium, l'himne era cantat alternatim per tot el cor i l'orgue. El primer salm es cantava a cant d'orgue, el segon s'alternava a cant pla amb l'orgue i el tercer a cant d'orgue. L'antífona la cantava el cor sol a cant pla, la capítula, el susdit domer i els versets dos doctors, un de cada cor. Acabada nona, es deia la Salve a cant d'orgue i, després, havent-se agenollat tots, es cantava el Tantum ergo Sacramentum, i es feia la reserva del Santíssim.

Vigília de Pentecosta. S'entrava a tèrcia a vuit hores i, acabada la nona, es deien les sis profecies, cantades pels sis Canonges més joves, tot començant pel més jove de tots, els quals havien estat convidats a fer-ho pel dormitorer. Acabades les profecies, s'anava en processó i en silenci fins a la porta de la sagristia, on dos escolans de cota de grana revestits de capa pluvial morada i acompanyats del dormitorer, cantaven ells dos sols, al mig de la clerecia, el tracte Sicut cervus. Aleshores, s'iniciava la processó per a la benedicció de les fonts baptismals, com s'havia 
fet el dissabte sant. Un cop feta la benedicció, els susdits escolans començaven el cant de les lletanies i es prosseguia també com el dissabte sant. A l'ofici, encara que de semidoble, hi havia orgue. Les vespres eren de doble major de primera classe. En començar l'himne Veni Creator Spiritus, tothom s'agenollava fins al final de la primera estrofa.

Dominica de Pentecosta. Festa de doble major de primera classe amb octava privilegiada, solemnitat que es manifestava en l'abundància de música, ja que a matines, laudes i prima, era tot cantat. Per a l'homilia s'invitava una dignitat, per a la segona lliçó un doctor i per a la tercera el domer que oficiava. Per al primer responsori es convidava un doctor i per al segon el canonge més antic. S'entrava a tèrcia a les nou i en començar l'himne Veni Creator Spiritus, tots s'agenollaven fins al final de la primera estrofa, rite que s'havia d'observar tota la vuitada, sempre que es cantés aquest himne, tant a tèrcia com a vespres. Dita la lletania, s'iniciava la processó "more solito", en la qual només hi havia dos responsoris, ja que només es feien dues estacions, això és, la primera davant de la sagristia i la segona abans d'entrar al cor, acabada la qual, tothom s'agenollava a una ordre del capiscol, per al cant del Veni Sancte Spiritus, entonat el qual, el capiscol repetia el senyal per aixecar-se i s'entrava al cor i es començava l'ofici. Aquest era a cant d'orgue a dos cors, com també el Magnificat d'ambdues vespres. Durant el cant del vers Veni Sancte Spiritus del gradual, tothom s'agenollava i acabat aquest, els beneficiats que tenien capa, invitaven tots els residents, cadascú els del seu cor, perquè baixessin davant del faristol major a cantar la sequiència, la qual era alternada pel cor i l'orgue. Després de vespres, s'anava a fer estació a una capella del claustre, on els oficials cantaven la seqüència Veni Sancte Spiritus.

La segona i tercera fèria de Pentecosta eren dobles majors de segona classe. Les matines es deien resades i les laudes i prima cantades "more solito", l'ofici es cantava a cant pla i a vespres el Magnificat no es cantava a cant d'orgue. Tampoc no es feia cap estació, després de vespres. Fora d'això, s'oficiava en tot com el dia de la Pentecosta. Els altres dies d'infraoctava, encara que de rite semidoble, hi havia orgue a l'ofici, però no a matines, ni a vespres.

El dissabte de la Trinitat, s'entrava a tèrcia a dos quarts de nou. Les quatre primeres profecies de la missa eren cantades pels escolans de cota de grana, la darrera, però, per un canonge, tots des del faristol major. La resta era tot com en els altres dies d'infraoctava de Pentecosta. Després de vespres, es feia estació a la capella de les Ànimes / Innocents.

Diumenge de la Santíssima Trinitat. Tan sols es diu que era festa doble major de segona classe. Cal concloure, en consequiència, que la música era d'acord amb la solemnitat descrita per a aquesta categoria litúrgica, al seu lloc corresponent.

Vigília, diada i octava de Corpus Cap. 24, f. 119v-123.

La festa de Corpus es va celebrar sempre amb gran manifestació externa, a Barcelona, no endebades, fou la primera d'Espanya i d'Europa a celebrar-la, ja amb processó i tot, l'any 1320, després que el papa Joan XXII la declarés festa universal, l'any 1316. El Manual, no sols es fa 
ressò de tanta festa i de tanta tradició, sinó que la manté i potencia, en el seu calendari, com podreu comprobar.

La Vigilia. S'entrava a vespres a l'hora acostumada de dos quarts de tres de la tarda i hi acudien els Consellers, mediant unes embaxades mútues, per prevenir-los pel que feia al moment d'arribar els susdits Consellers a la catedral. Però l'any 1685, acabant-se el Benedictus, encara no eren arribats i s'interromperen les matines al darrer vers del susdit càntic i sonà l'orgue durant mitja hora. Quan van arribar els Consellers, entonaren el Gloria Patri. Aquest inconvenient, fou la causa que en endavant el Capítol decidís començar aquest acte mitja hora més tard. Les matines eren cantades amb solemnitat, però es recomana que acabessin abans de les sis. En aquestes vespres, no es cantava res a cant d'orgue. A matines, però, es cantaven a cant d'orgue el Te Deum, Benedictus i Salve i, tot seguit, s'anava a fer estació a l'altar de Corpus Christi del claustre, a la qual també hi anaven els Consellers amb llur acompanyament.

El Dia de Corpus, doble major de primera classe, s'entrava a tèrcia a les nou. Es cantava l'ofici a cant d'orgue a tres cors. A vespres s'entrava a dos quarts de tres, o a les tres, si s'havia sortit tard de l'ofici. El primer vers ${ }^{6}$ de l'himne Tantum ergo..., malgrat correspondre a l'orgue sol, era cantat per tot el cor, i també tota l'octava, per ser aquest l'estil de l'església. A la processó, a la tarda, quan començava a sortir el clergat, els quatre capiscols entonaven tots junts el Te Deum i, durant la processó, es cantava l'himne Sacris solemniis. En arribar a Santa Maria (crec que s'ha d'entendre Santa Maria del Mar), els quatre capiscols s'havien d'aturar davant del presbiteri, mentre els cantors de la Seu hi cantaven un motet. El Corpus de l'any 1690, s'ajornà la processó al diumenge següent, per pluja (v. fol. 130) i el 1697 (v. fol. 131), es celebrà de manera excepcional per dins de l'església i pel claustre, degut al setge de la Ciutat per l'exèrcit francès. Hi ha constància que es cantà un villancico, davant de la Concepció. Quant a l'octava, diu el Manual que, a la catedral, es celebrà amb la solemnitat de costum, llevat que, en lloc de la siesta $^{7}$, de tres a quatre, es digueren salms.

El divendres, dia següent de Corpus, s'entrava a matines, a l'hora acostumada i tant les matines, com les laudes i prima es deien resades, encara que es tractava d'un doble. A les nou, s'entrava a tèrcia $i$, acabada sexta, anava tot el clergat amb ciris encesos i en processó al presbiteri, tot cantant l'himne Pange lingua, el qual s'havia de cantar sencer. En arribar, però, al vers/estrofa Tantum ergo, tothom s'agenollava i es descobria el Santíssim. Acabat l'himne, tornaven "al cor sens llum a la desfilada" i deien la nona i la lletania. Tot seguit, es celebrava l'ofici, que era cantat a cant d'orgue a dos cors, llevat de l'introit i el gradual, els quals eren cantats a cant pla, i la seqüència, cantada alternativament pel cor i l'orgue. Acabat l'ofici, es quedaven

6. El Manual acostuma dir "vers" al que nosaltres diem "estrofa".

7. Josep Pavia i Simó: "Documents per a la història de les capelles de música de Barcelona aa.1763-1820", AnM 37, 1982, (1983), pp.107-108, nota al peu, n 18: “Amb el mot "Siesta" sembla que s'ha d'entendre l'estona que es dedicava a les esglésies, en certes solemnitats i a primera hora de la tarda, a interpretar música no "estrictament" litúrgica. El present document, als paràgrafs 16,17 i 19, ens permet, a más a més, esbossar el que seria una "Siesta", a la qual, si considerem la seva solemnitat, hi podien participar o no participar, violins i oboès, podia intervenir tota la capella o només part d'ella. I, si tenim en compte el programa musical que s'interpretava, hom s'adona que s'insinua una doble possibilitat: a) Simfonia més "Villancicos" - aquests amb ària o sense-, i b) Sinfonia més Oratori". 
a fer la vetlla al Santíssim aquells canonges i beneficiats designats cada dia de l'octava pel seu torn, els quals havien de cantar de tant en tant i "submissa voce" els himnes de la festivitat de Corpus. S'entrava a vespres a les dos, i s'havien de dir amb tal solemnitat, que, entre vespres i completes, havien de durar fins a les tres. Hi havia orgue. A les tres, tenia lloc la siesta, la qual també durava una hora. A les quatre començaven les matines cantades. Els dormitores cantaven l'invitatori i responia el conjunt, o els altres oficials cantors. L'himne era cantat alternativament per l'orgue i per tot el conjunt. Les antífones eren entonades pels escolans de cota de grana, els quals també cantaven els versets dels nocturns. Dels salms tenia cura el dormitorer setmaner, el qual també invitava els qui havien de cantar les lliçons, per aquest ordre: primera lliçó: un doctor; segona: un beneficiat; tercera: un canonge; quarta i quinta dos beneficiats; la sisena: un canonge; l'homilia, la cantava el diaconal tota la setmana, "ex officio"; l'octava: un doctor; la darrera, l'havia de cantar el domer menor que feia la doma. Totes les lliçons es cantaven a la troneta. Per cantar els responsoris, també invitava el mateix dormitorer, d'aquesta manera: per al primer responsori: un doctor de cada cor; per als segon, quart, cinquè i setè: un beneficiat de cada cor, per a cada responsori; per als tercer i sisè: canonges; per al vuitè: doctors. El Te Deum l'entonava el dormitorer i era cantat alternativament amb l'orgue.

Les antífones de les laudes les entonaven els susdits escolans de cota de grana i els salms el dormitorer. L'himne i el Benedictus eren cantats alternativament amb l'orgue. El vers/estrofa $O$ salutaris hostia era cantada per tots, agenollats, encara que toquès l'orgue.

Acabades les matines, segons el Manual, però crec que s'ha d'entendre que també les laudes, amb la Salve resada a tres quarts de sis, s'anava amb llum a la mà al presbiteri, tot cantant l'himne Sacris [solemniis], alternant amb l'orgue, on s'agenollaven, fins que sonaven les sis. Aleshores, si l'himne no s'havia acabat, s'interrompia, es deia la col·lecta i feien la reserva del Santíssim. Donat que el Manual no diu res més, cal interpretar que s'anava a la sagristia i que la cerimònia era finida.

El dissabte, s'entrava a prima a sis hores, i es deia tan sols aquesta hora cantada, si no fos que hi haguessin pocs residents, ja que en tal cas es deia resada. Tèrcia, hores, ofici, vespres $i$ matines, es deien a l'hora i en la forma que s'ha dit del divendres.

El diumenge infraoctava, s'entrava a tèrcia a les nou i, dites les hores menors i la lletania, tenia lloc la processó i, acabada la qual, es tornava al cor i s'hi entrava entonant el Pange lingua, es prenia llum i s'anava al presbiteri a descobrir el Santíssim, el qual descobert, proseguia la cerimònia com els altres dies de l'octava. Després de vespres, però, s'anava a fer estació a l'altar major.

El dilluns i dimarts, s'oficiava en tot, com el divendres i dissabte.

El dimecres, després de vespres, s'anava a fer estació a l'altar major. A matines, els canonges assistien amb llums al cant de l'invitatori, com s'acostumava en les matines cantades amb solemnitat. L'homilia la cantava un canonge, per tractar-se d'un doble.

El dijous cap d'octava de Corpus s'entrava a vespres a dos quarts de tres, l'hora de vespres a l'estiu. Després de completes, es feia la professó per la plaça de Sant Jaume, Llibreteria i plaça del Rei, en temps normal: Però, si plovia, es feia per l'església i el claustre. En iniciar-se 
Josep PAVIA I Simó

la processó, els capiscols entonaven el Te Deum i, en el decurs de la processó, l'himne Sacris solemniis. A la plaça del Rei, es cantava «un villancico».

\section{Dominiques “per annum» Cap. 25, f. 126.}

Aquests diumenges, matines, laudes i prima es deien tot resat, però la tèrcia s'havia de cantar amb molta solemnitat i pausa, com els dies dobles majors de primera, o segona classe. L'antífona de tèrcia, sexta i nona, l'entonaven els escolans, el dormitorer els salms i beneficiats invitats pel dormitorer s'encarregaven dels versets de les susdites hores. Acabada la lletania, els capiscols, amb bordó i sense capa, havien de prosseguir l'Asperges, entonat pel missa cantant (pel text, hom dedueix que no tot sols). Efectivament, tot sols havien de cantar el Miserere mei Deus, el Gloria Patri et Filio et Spiritui Sancto i l'inici, a la repetició, de l'Asperges me Dne., el qual era cantat pel cor. Després de fer l'aspersió, s'iniciava la processó rodejant l'església, tot fent estació davant de l'altar de les ànimes, de la sagristia i abans d'entrar al cor. Quan s'entrava al cor, s'acostumava de cantar una antífona del comú de verges, per santa Eulàlia, patrona de l'església, a no ser que s'encertès la commemoració d'algun sant, ja que en tal cas es cantava una antífona convenient al susdit sant. Es cantava tot a cant pla.

\section{Pràctiques i costums particulars de la Seu barcelonina}

\section{De la hora que s'acostuma entrar als officis en nostra Igla. en tot lo temps del any. Cap.}

26, f. 127-130v.

1. De l'hora de matines (f. 127). Des del dimecres de cendra fins a sant Miquel, exclòs, s'entrava a sis hores del matí. De sant Miquel fins al darrer dia d'octubre, s'entrava a dos quarts de set. El primer de novembre es començava a entrar a les set i així fins al dimecres de cendra, exclòs. Tot això, d'acord amb la resolució capitular del 7 de juliol de 1681. Però el 13 d'agost del 1688, es prengué l'acord d'entrar a l'hora que disposava la visita del bisbe de Barbastre, això és: del primer de maig fins al 29 de setembre, s'entraria a dos quarts de sis del matí, del 29 de setembre fins al primer dia de la quaresma, a dos quarts de set i des del primer dia de la quaresma fins al primer de maig, a les sis.

2. De l'hora de tèrcia (f. 127v.). A tèrcia, sexta, nona i ofici, s'entrava a dos quarts de nou. Aquest horari era el propi de la quaresma, exceptuant-ne aquells dies, en què no hi havia prèdica i els diumenges, en què s'entrava a les nou. Els dies de doble major que s'esqueien en quaresma, també s'entrava a dos quarts de nou, encara que es celebrès de la susdita festa, ja que les vespres s'havien de dir pel matí. En les tres festes de pasqua de Resurrecció, s'entrava a nou hores, en la fèria quarta, però, es començava a entrar a tèrcia a les vuit, fins al 29 de setembre exclòs, a partir del qual fins a l'advent, s'hi entrava a dos quarts de nou. A l'advent, es 
començava la tèrcia a les nou fins que s'eren passades les festes de Nadal, després de les quals s'entrava novament a dos quarts de nou. Els dies de festa obligada i els de dejuni de precepte, s'entrava a les nou, fins i tot en el temps, en què s'entrava a dos quarts de nou; $i$ els dies de doble major que no eren festa obligada, no es canviava l'hora de tèrcia, sinó que es mantenia la corresponent al temps en què s'esqueia. Però, quan s'entrava a les nou, aquesta hora no es mudava, si no era els dies que hi havia prohomenia, en virtut d'una concòrdia feta entre el Capítol i la Ciutat.

3. De l'hora de vespres (f. 128v.). El primer diumenge de quaresma, s'entrava a vespres a dos quarts de tres de la tarda i aqueixa norma s'observava els diumenges de quaresma, en els quals es deien les vespres a la tarda, perquè els altres dies de quaresma, es deien les vespres al matí, després de la prèdica, com s'ha dit al capítol setze. Aquest horari tenia vigència fins al dia de sant Miquel, exclòs. Des de sant Miquel fins al primer diumenge de quaresma, s'entrava a un quart de tres.

4. De les diadas que se entra a hora extraordinaria (f. 129-130v.).

Gener. El dia set, festa de sant Ramon i el dia 20, festa de sant Sebastià, s'entrava a tèrcia a les vuit, perquè s'anava en processó, respectivament, a santa Caterina i a sant Sebastià.

Març. El dia 15, s'entrava a tèrcia a les set, perquè s'anava en processó a santa Madrona.

\section{Dels tres Aniversaris que se acostuman fer per la Ciutat lo Dissapte dilluns y Dimars de Carnestoltas. Cap. 27, f. 133.}

Aquests dies, s'acostumava a entrar a tèrcia a les nou i es feia aniversari per la Ciutat. Era costum que hi assistissin els Consellers amb gramalles negres, sense prohomenia, però. Es cantava a cant figurat a dos cors, baix a les cadires, exceptuant-ne el vers Absolve i Hostias et preces, els quals es cantaven a cant pla. Acabat l'ofici, es cantava una absolta a cant figurat, estant la clerecia i els del gremial al voltant del túmul. Després, encara se'n feien quatre més, d'absoltes, al claustre, una a cada cantonada, havent d'ésser la darrera el Requiem aternam.

Es posa de relleu que el 16 de novembre de l'any 1684, a instància de la Ciutat, es féu el mateix aniversari, però en lloc de les quatre absoltes pel claustre, només se'n feren tres a cant d'orgue, al voltant del túmul i sense sortir al claustre. Hi assistiren el bisbe al cor, el Lloctinent a la tribuna i els Consellers al presbiteri. Aquest aniversari es celebrà pels qui moriren a la Galera Capitana d'Espanya, la qual es perdé al Port de la present Ciutat, el 9 del susdit novembre. Hom creu que hi moriren uns quatre cents homes.

\section{Diferents exemplars}

El Manual recull, fins al final del manuscrit, diferents exemplars de circumstàncies més especials, no contemplades en l'estructura litúrgica, pròpiament dita, en les quals, però, solia 
haver-hi cant. En alguna, com la de les pregàries per pluja, hom hi valora la descripció que s'hi fa de les "cambres angelicals", les quals explica amplament el Manual, si bé no dóna l'origen d'aquesta denominació.

Combregar de Bisbe. Cap. [27] f. 134.

El 19 d'abril de 1697, s'esdevingué el combregar del bisbe Emmanuel d'Alba. El document diu expressament que totes les pregàries havien estat fetes sense cant.

Sepultures de Bisbes. Cap. 28, f. 135.

El dimarts 23 de desembre de 1692, morí el bisbe de Barcelona, Fr. Benet Ignasi de Salazar, de l'orde de sant Benet, pel qual es féu la sepultura acostumada, amb els següents apartats amb música:

El 24 del susdit mes, al matí, després de l'ofici, es va anar a fer absolta. Encara al cor, dos escolans de grana entonaren l'antífona Dirige i el capiscol i el succentor el salm Verba mea pel to setè, L'absolta fou general a cant d'orgue. Mentre en tornaven, es digué el salm Miserere, en veu baixa. Després de completes, s'hi tornà a anar a fer una altra absolta, com al matí. També hi van anar, durant el dia, totes les parròquies i convents. El dia següent, per ser Nadal, no s'hi va anar a fer cap absolta, pel matí, però a la tarda, tothom hi va anar. El 26, s'hi anà a fer absolta pel matí i després de completes.

El 27, dia de sant Joan, doble major, s'entrà a matines a l'hora acostumada, però en aquestes, a laudes i a prima es digué tot resat, malgrat tractar-se d'un doble major. Tot seguit de prima, es digueren les hores de tèrcia, sexta i nona, però aquestes hores foren cantades i també l'ofici, com en els dobles majors. Ordenat en processó el clergat de parròquies, dos escolans entonaren, encara dins del cor, l'antífona Dirige i els capiscols entonaren el salm Verba mea, trobant-se entre el cor i el portal major. El Manual, en aquest punt, indica que el salm fou entonat dues vegades. Possiblement, el moviment de la processó va donar temps per fer-ho. El text, “ad litteram”, diu:

"Comensa lo Cabiscol en compañia dels Obrers a ordenar la Professo desta manera. Passada la Creu de la Seu tant solame[n]t i cridat tot lo Clero de las Parrochias y estant a punt los Cabiscols de Parrochias ab sas capas y bordons prop del portal major aná lo Cabiscol ab sos habits sens capa al mitg de ells, y despres de haver entonat dos escolans de grana: Dirige, entonaren tots junts: Verba mea etc. y luego se parti tot lo Clero; Fora que fou lo Clero cridaren totas las religions per son orde y luego despres isqué lo Claro de la Seu, entonant entre lo cor y portal major los Cabiscols ut supra: Verba mea etc."

En ser arribats a la porta del palau episcopal, on era el fèretre, els cantors cantaren el Subvenite, entonaren el salm In exitu i s'inicià el retorn, tot fent el recorregut del dia de Corpus, 
però al revès i, a mès, no s'entrà a Santa Maria del Mar. Durant el recorregut, es feren vuit absoltes a cant d'orgue: la primera en la plaça de Sant Jaume, la segona davant de sant Cristòfol, la tercera als quatre cantons del carrer Ample que va a la font de l'Àngel, la quarta al cantó que gira envers els Camins, la cinquena davant de la vicaria de Santa Maria, la sisena davant de la capella d'en Marcus, la setena a la plaça de la Llana i la vuitena a la plaça de l'Àngel i, en entrar al cor, una altra a cant pla. Tot seguit, es digué l'ofici (enteneu de difunts), el qual excepcionalment es digué a l'altar major. Els músics cantaren a la troneta i l'epístola i evangeli al presbiteri. Acabat l'ofici es féu encara una absolta més i, la resta, com a les sepultures de canonge. Després es deixà el fèretre a la nova capella de sant Oleguer i es tancà. Al vespre, fou enterrat al vas dels bisbes.

Els 29 i 30, es digueren els dos oficis de la sepultura, com en les sepultures canonicals i el dia trenta, a la tarda, es digueren les matines de morts. El 3 de gener de 1693, es celebrà el cap d'any, com en les canonicals.

El 22 d'abril de 1697, morí el bisbe Emmanuel d'Alba, el qual havia estat combregat el 19 del susdit mes i any, com s'ha dit més amunt. Els dies 23, 24 i 25 del susdit mes i any, després de l'ofici, al matí i després de completes, a la tarda, anaren a fer les absoltes establertes, com s'ha dit més amunt, en la del bisbe Fr. Benet Ignasi de Salazar.

El dia 26, s'entrà a laudes a l'hora de costum i laudes i prima foren cantades. També a tèrcia s'entrá a l'hora normal de les vuit $i$, després de completes s'anà en processó al Palau del bisbe, seguint, més o menys, el ritual desplegat també per a la sepultura del bisbe Salazar.

El dia 27, es digué el segon ofici de la sepultura, tot cantant els músics baix al cor i després es féu una absolta a cant d'orgue al vas dels bisbes. A la tarda, després de les vespres del dia, es digueren les de morts amb rite de doble resades i, després de les completes, es digueren les matines de morts cantades. El tercer ofici no es pugué dir el dia 28, per ser diumenge i s'ajornà al dia 29 següent. El 30, es féu el cap d'any.

Sepultures Canonicals per Canonges. Cap. 29, f. 139.

La vigília de l'enterrament, després de completes, el Capítol i la clerecia anaven a la casa del difunt a fer una absolta general, però, abans de sortir del cor, dos escolans de grana entonaven l'antífona Dirige, davant del faristol major i, tot seguit, el capiscol i el succentor, des del mateix lloc i revestits amb capa pluvial negra i bordó, entonaven el salm Verba mea, etc. pel to setè. Aleshores, partia la processó, cantant el susdit salm, el qual conclòs, entonaven el Miserere mei Deus, etc. En arribar a la casa del difunt, s'interrompia el salm i es deia Requiem aternam, etc. i es repetia l'antífona Dirige. Llavors tota la clerecia pujava a la sala on era el cadàver i es cantava l'absolta a cant d'orgue, acabada la qual, el bisbe, si hi assistia i, si no, el domer major setmaner, deia les col-lectes prescrites pel Manuale parochorum $i$ s'iniciava el retorn a la catedral, seguint un itinerari diferent d'aquell, pel qual havien anat, resant "aliquantulum submissa voce" el salm Miserere, etc. 
El dia de l'enterrament, després de dir la lletania, s'iniciava la processó cap a la casa del difunt, de la mateixa manera com s'ha dit per a la vigília. En arribar al portal de la casa i, després de repetir l'antífona Dirige, els cantors cantaven el respons Subvenite, a cant figurat "et reliqua ut in manuali parochorum". En sortir de la casa del difunt, els capiscols entonaven el salm In exitu Israel, pel to setè, alternant un vers el clergat a cant pla i un altre els cantors a fals bordó. Pel camí s'havia de fer estació i absolta, davant d'una església, si n'hi havia cap i, si no, en alguna plaça. Quan s'arribava a la catedral, s'interrompia el salm i s'entonava a cant pla l'absolta o respons Libera me D[omi]ne, i s'anava cantant fins al lloc, a on s'havia de dipositar el cadàver. Acabada l'absolta, es deia l'ofici, cantat a cant figurat, àdhuc la Sequentia, exceptuant-ne el tracte Absolve i els dos versos següents, els quals eren cantats pel capiscol i succentor a cant pla. Acabat l'ofici, es feia una absolta a cant figurat, després de la qual dos escolans de grana, entonaven a prop dels capiscols, l'antífona In Paradisum ducant te Angeli in tuo adventu suscipiant te Martyres et perducant te in Civitatem Sanctam Hierusalem. Llavors, els capiscols entonaven el salm Ad te Dne. levavi animam meam: Deus meus in te confido non erubescam, pel to setè. Un cop dit el primer o més versos (si el cadàver s'havia d'acompanyar a un vas fora del cor), es deia requiem i es repetia sencera l'antífona In Paradisum, acabada la qual, els capiscols deien Kyrie eleison, etc. i el celebrant, dita l'oració, entonava l'antífona Ego sum resurrectio et vita, i els capiscols el Benedictus pel to segon i, repetida la qual antífona, els capiscols havien de dir Kyrie, etc. i requiescat in pace, després de les oracions. A la tarda, després del Benedicamus Dno. de vespres, es deien les vespres de morts resades "ritu duplici" i acabades aquestes, es deien les completes. Aleshores, els capiscols prenien capes negres i començaven les matines de morts cantades amb la mateixa solemnitat del 2 de novembre, com s'ha dit al seu lloc.

Els dos dies següents a la sepultura, es deia ofici a cant d'orgue a la troneta, però la prosa era cantada a cant pla i es feia una absolta.

Després de tot això, el primer dia de doble que s'encertava i no era d'obligació, es feia el cap d'any, en el qual es deia la missa del corrent a l'altar major i, després de l'ofici, es feia una absolta. Tot era cantat a cant pla, com en els dobles menors "per annum".

També es recullen exemplars de sepultures de canonges, ocorregudes en dies impedits per altres celebracions i, aleshores, s'alterava alguna cerimònia.

Exemplars de Pregarias per Pluja. Cap. f. 145-150

És molt curiós la freqüència, amb què es celebraven rogatives per la pluja, a la Barcelona del s. XVII, presidides, evidentment, per la nostra catedral, fins al punt d'establir-se'n la corresponent normativa i el fet que, quasi bé sempre, s'anava solemnement a l'església de santa Madrona, per dur-la a la catedral i per tornar-la, després, al seu lloc.

El Manual recull diferents exemplars de les pregàries que es feren els anys 1687, 1689, 1691 i 1700. Donat que les de l'any 1687 són més completes, les resumiré i em donaré per excusat d'explicar les altres. Cal dir que també es feien pregàries per serenitat, com succeí l'any 1692 
i ho explicaré després. De les d'abril de 1687, hom llegeix al Manual que s'havien de fer "en la forma acostumada".

Efectivament, el 9 del susdit mes i any, el Capítol rebé una petició del Síndich de Ciutat en vistes a fer pregàries per la pluja i, en consequiència, el 10, no es digué la lletania al cor, sinó que, després de nona, s'inicià una processó per l'església i, en ser arribats a l'altar major, s'agenollaren i els canonges més antics, un de cada cor, invitats pels capiscols, entonaren la lletania fins a la invocació Sancta Maria. Llavors tots s'aixecaren i anaren dret al cor i després de rodar tota l'església, baixaren a Sta. Eulàlia, a fi d'acabar de la manera com estava previst en uns llibrets especials per a semblants funcions, els quals es guardaven en la sagristia. Després de les lletanies, es deia (cantat?) el salm 146, el començament del qual és així: Laudate Dominum, etc.

A 11 del mateix mes d'abril, després de completes, el dormitorer entonà la Salve Regina i, mentre era cantada, tota la clerecia baixà a santa Eulàlia i, un cop acabada, el mateix dormitorer, estant tots els altres agenollats, entonà el Monstra te esse Matrem i també s'agenollà. Aquesta estrofa es va cantar dos cops més, després dels quals, els escolans digueren els versets i el domer les col-lectes.

El dia 12, es féu tot com el dia 10.

El 13, no es féu res, per ser diumenge i haver-hi un sant de doble.

El 14, els Consellers presentaren al capiscol la petició dels hortelans, els quals veient com se'ls perdia tota l'anyada, instaven que s'anès a cercar el cos de santa Madrona, el qual capiscol reuní el Capítol, el dia següent al de la petició que li havien fet i es prengué l'acord d'anar a cercar el cos de la santa, el dia 16, al matí. Es va entrar, doncs, a matines a l'hora acostumada, però matines, laudes i tèrcia foren resades. Tèrcia començà a les set, immediatament després de prima i la missa conventual s'inicià juntament amb l'hora de sexta, com el dia de sant Marc, a 25 d'abril. Acabat l'ofici, s'organitzà la processó. Els capiscols, com de costum, invitaren dos canonges dels més antics i tots quatre, agenollats al presbiteri, cantaren les lletanies fins a Sancta Maria. Llavors s'aixecaren i continuaren cantant-les, com s'ha dit el segon dia de rogatives. La processó procedí per la Plaça Nova, Portaferrissa i carrer del Carme, fins al Portal de Sant Antoni. Durant el recorregut, observaren aquesta pràctica: davant d'una capelleta de la Portaferrissa, el capiscols, aturats i girats devers la susdita capelleta, digueren dues vegades Sancta Maria, a la primera de les quals respongueren Ora pro nobis i a la segona Intercede pro nobis. Així mateix es féu davant de la porta de l'església del Carme. Davant de les següents esglésies, s'invocà, però, el seu patró o patrona: davant de les Mínimes, sant Francesc; davant de les Caputxines, santa Margarida; davant de les Gerònimes, sant Geroni i davant de sant Antoni, aquest sant. A partir del Portal de Sant Antoni, la processó "anà a la desfilada", fins a la Creu de santa Madrona, sense cantar res. Aquí es reféu la processó i es reprengueren les lletanies, des d'Omnes Sancti et Sanctce Dei, les quals lletanies s'acabaren estant tota la clerecia agenollada a l'església de la Santa. Tot seguit es celebrà un ofici a cant d'orgue, com en la festa de santa Madrona. Després, es baixà el cos de la santa i es posà sobre la civera i partí la processó, entonant els capiscols el Regina cali laetare, i, a la porta de l'església, agenollats, l'himne Ave maris stella, el qual es continuà cantant fins al portal de Santa Madrona, a on la processó tornà a anar "a la desfilada" fins 
al Portal de Sant Antoni. Aquí entonaren novament l'Ave maris stella, i "se continua ab los ministrils y segos fins a la seu" i finiren l'himne a l'altar major, on deixaren el cos de la Santa.

El dia 17, es féu tot com està notat el dia 10, només que les lletanies finiren a l'altar major, per trobar-s'hi el cos de la Santa.

Dia 18. No es féu res, però reconeix el Manual que fou un descuit no cantar la Salve després de completes.

El 19, feren la processó per l'església, com el dia 17.

El dia 20, diumenge, es digué la Salve, després de completes.

El 21, una embaixada de la Ciutat exposà al Capítol la necessitat que hi havia d'aigua i, aquest, resolgué fer les processons anomenades de "les set Cambres Angelicals", que foren les següents:

$1^{a}$ Cambra Angelical de Natzaret. Dia 22. Es va entrar a matines a l'hora acostumada i tant aquestes, com les laudes i prima, es digueren resades. A tèrcia s'entrà a les set i es digueren les hores cantades "more solito". Després de nona i sense la lletania, es celebrà un aniversari canonical a cant d'orgue i, tot seguit de l'ofici, els quatre capiscols iniciaren les lletanies al presbiteri, com s'havia fet per anar a cercar santa Madrona. S'hi anà per les escales, Plaça Nova, Plaça i carrer de Santa Anna, Tallers ("Tellers", al ms.), etc. Davant de sant Gaietà, els capiscols digueren dues vegades Sancte Mathia, amb les consabudes respostes d'Ora pro nobis i Intercede pro nobis, invocacions que es repetiren davant de Montesió (Sancta Maria), davant de Santa Anna (Sancta Anna) i davant d'una capelleta que hi havia al carrer Tallers (Sancte Joannes Baptista). Després d'haver passat el Col·legi del Bisbe, digueren: Omnes Sancti et Sancta Dei, etc. A Natzaret, es digué l'ofici De Anuntiatione, el qual cantaren les monges a cant pla. Acabat l'ofici, es tornà a la catedral, seguint les mateixes cerimònies del dia de sant Marc, al partir de l'Hospital, per davant del Col·legi del Bisbe, Àngels, carrer del Carme, Portaferrissa, Plaça Nova i per santa Llúcia.

El 23, es cantà la Salve baix, a santa Eulàlia, però no es féu processó, per ser festa d'obligació.

$2^{a}$ Cambra Angelical de St. Agustí. Dia 24. Es féu tot com el dia 22, per anar a Natzaret, però l'itinerari fou aquest: per la Borja i sant Cugat. Davant de la volta de Santa Caterina, es feren les dues invocacions a la santa i també dues a sant Ramon i davant del Portal de St. Jacint, dues a sant Diumenge i dues al susdit St. Jacint; a la capella d'en Marcus dues invocacions a Santa Maria i davant de sant Cugat, invocaren dues vegades aquest sant. Arribats a Sant Agustí, entraren a la capella de la Pietat, on es celebrà l'ofici De Nativitate Domini, a cant pla, el qual ofici digueren i cantaren els religiosos. En tornar, des de la capella de la Pietat fins a l'església de Sant Agustí, cantaren el Regina caeli i, en ser a Sant Agustí, la processó hi passà per dins i, al

8. Als folis 180ss, hi ha l'exemplar d'altres "Cambres Angelicals", de l'any 1717, però no són tan l·lustradores com aquestes. 
portal del patí, entonaren l'Ave maris stella. Es passà pel carrer de Sant Pere més baix, Riera de Sant Joan i escales de la Seu... La resta, com el dia 22.

El 25, s'anà en processó a l'Hospital, com tots els anys.

$3^{a}$ Cambra Angelical al Pi. Dia 26. Després de fer-se tot, a la catedral, com els precedents dies de les Cambres, s'anà al Pi per les escales de la Seu i carrer dels Boters i, al tornar, per davant de la Vicaria del Pi, Boqueria ("Bocaria", diu el Manual), etc. Es digué l'ofici o missa de Epiphania Domini, el qual digueren els capellans del Pi i cantaren juntament els clergues de l'esmentada església i els de la Seu, donat que es trobaven tots dins del cor. La resta, com els dies 22 i 24.

El dia 27, es digué la Salve baix a santa Eulàlia, però no es féu processó, per ser diumenge. $4^{a}$ Cambra Angelical al Carme. Dia 28. Es féu tot com els dies precedents. La processó anà per les escales de la Seu, Plaça Nova, Boters i Portaferrissa i entrà a l'església del Carme i en sortí per la porta que dóna al carrer del mateix nom i, passant per dins de l'església de l'Hospital, sortí al carrer de l'Hospital, Boqueria, Call i Plaça de St. Jaume, fins a la Seu. Al Carme, els religiosos digueren i cantaren la missa De Resurrectione Domini.

$5^{a}$ Cambra Angelical a la Mercè. Dia 29. S'hi anà per davant del Palau del bisbe, Plaça de St. Jaume, Regomir i Carrer Ample i, davant dels "Escudellers blanchs", girà dret a la Mercè, entrant-hi pel portal major de l'església. En ser davant de St. Jaume, St. Just i St. Pastor i St. Cristòfol, invocaren dos cops aquests Sants, com manava el ritual. A la Mercè, els religiosos de l'església digueren i cantaren la missa De Ascensione Domini. De tornada, sortiren de l'església per la porta del carrer Ample i la processó anà pels Escudillers blancs, Plaça de Sta. Verònica, devallada de St. Miquel, Plaça de St. Jaume, etc., com els dies anteriors.

El dia 30, hi hagué sepultura canonical, la qual impedí la processó i demés, ja que, tot seguit de completes, començaren les matines de morts per la susdita sepultura.

El primer dia de maig del susdit any 1687, no es féu la processó, per ser festa d'obligació, però s'anà a cantar la Salve baix a Sta. Eulàlia, després de completes.

$6^{a}$ Cambra Angelical a Junqueres. Dia 2. Hi anaren per les escales de la Seu, Carreró de la Taverna de l'Infern i Riera de St. Joan, on s'aturaren i els capiscols invocaren sant Joan Baptista i, davant de les Madalenes, invocaren santa Maria Magdalena. Un cop a Junqueres, els capellans de les monges digueren la missa $i$, aquestes, la cantaren. La processó tornà pel carrer Comtal, plaça de Sta. Anna, plaça Nova i per davant de santa Llúcia.

El dia 3, baixaren a dir la Salve a santa Eulàlia, després de completes.

El dia 4, només digueren la Salve a santa Eulàlia, després de completes, per ser diumenge.

El dia 5, ocorregué la fèria segona "rogationum" i, per estar el temps molt núvol i haverhi molt de fanc, es resolgué fer la processó per l'església i el claustre, d'acord amb el cerimonial per a aquestes ocasions. Es feren absoltes davant de St. Marc, davant de la sagristia i als quatre angles del claustre i una setena, un cop tornats dins de l'església. La processó finí baix a santa Eulàlia, on el domer menor digué l'ofici, assistit pel diaconal i el subdiaconal. L'ofici fou cantat a cant d'orgue. A la mateixa cripta, fou cantada la Salve, a la tarda, després de completes. 
El dia 6, tingué lloc la tercera fèria "rogationum". S'anà a Santa Maria del Mar i, després de completes, digueren la Salve baix, a santa Eulàlia.

El dia 7, fèria quarta "rogationum", celebraren la processó i l'ofici com el dia 5, per les mateixes raons de pluja i fanc. Les absoltes, però, aquest dia n'eren onze, les quals es repartien i es deien de la manera següent: una davant de St. Marc, dues davant de la sagristia, al primer quartó del claustre una, al segon, una a cant d'orgue, una al tercer i una altra al quart i, un cop dins de l'església, dues a cant d'orgue i una a cant pla.

El dia 8, festa de l'Ascensió del Senyor, es digué la Salve baix a santa Eulàlia, tan solament.

$7^{a}$ Cambra Angelical a Sta. Maria del Mar. Dia 9 de maig de 1687. S'entrà al cor a dos quarts de vuit $i$, en començar sexta, es digué també l'ofici, com el dia de St. Marc i Sta. Madrona, i, després s'anà en processó a Sta. Maria del Mar. En aquesta ocasió, la clerecia de Sta. Maria, no va sortir a rebre la processó al lloc de costum i obligació ${ }^{9}$ i el Capítol resolgué no entrar a Sta. Maria, sinó que, voltant pel Fossar, s'encaminà a l'Argenteria i tornà a la Seu, on es digué l'ofici De Assumptione B. M. V. -el qual s'havia de dir a Sta. Maria-, baix a santa Eulàlia i a cant d'orgue. La processó, d'anada a Sta. Maria, havia seguit l'itinerari del dia de Corpus.

Els dies 10, 11 i 12, no es féu altra cosa, sinó la Salve, després de completes, baix a santa Eulàlia.

El dia 12, el Capítol notificà a la Ciutat (enteneu l'Ajuntament) que ja s'havien fet les set processons de les set Cambres Angelicals i que, acabades aquestes, era costum de repetir-les, en el cas que persistís la necessitat de pluja. La Ciutat respongué que els pagesos insistien que s'en fessin més. Però no hi hagué necessitat, ja que abans que el Síndic del Capítol tornés la resposta de la Ciutat, plogué i, aleshores, demanaren que es cantés el Te Deum laudamus, en acció de gràcies per la pluja, el qual fou cantat el dia 15, després de l'ofici, rodant per l'església.

El Manual posa de relleu, a més, que tots els dies que duraren les susdites rogatives, exceptuant-ne els dobles majors i els que tenien estació, a vespres i laudes, després del Benedicamus Dno., es deia l'antífona Dne. Rex Deus Abraam, verset i oració "pro pluvia", estant tots agenollats.

El 21 de maig del susdit any 1687, el Síndic de la Ciutat demanà al Capítol que es tornés santa Madrona a la seva església, devolució que tingué lloc el dia 23. Aquest dia s'entrà a cor a les cinc del matí i es féu tot resat, com el dia de santa Madrona, ja que l'ofici solemne s'havia de dir a l'església d'aquesta santa. La processó s'inicià amb el cant del Te Deum.

\section{Altres exemplars de pregàries per la pluja}

Com s'ha dit més amunt, encara hi ha altres exemplars de pregàries per demanar la pluja, corresponents als anys 1689 (fol. 150v), 1691 (fol. 152) i 1700 (fol. 154), els quals presenten

9. Qui sap si aquesta actitud estava relacionada amb el plet que la Seu portava contra les capelles de cant de les parròquies de Barcelona, per anar a cantar fora de llurs esglésies, infringint els drets de la susdita Seu (v. Pavia i Simó, J., La música a la catedral de Barcelona, durant el segle XVII, ed. Fundació Salvador Vives i Casajuana, Barcelona, 1986, pg. 33ss.) 
algunes circumstàncies especials, però bàsicament consta que foren semblants a les referides anteriorment.

Pregàries per la serenitat fol. $153 v$

També hi ha un exemplar de pregàries per demanar serenitat del temps, quan la pluja era excessiva. Efectivament, el dia 11 de gener de 1692, es prengué l'acord d'exposar el Santíssim, el diumenge següent, dia 13, i de fer processons per dins de l'església el dimarts i dissabte, les quals duraren fins al 4 de febrer, data en què el Capítol resolgué suspendre les processons, però continuar amb la col·lecta "pro serenitate", fins a l'altra deliberació, la qual tingué lloc el 13 de març. Aleshores i a instàncies de la Ciutat, acordaren cantar un Te Deum, el dia següent, això és, el 14 de dit mes. Fora d'aquest cant, no hi ha constància de més cants. De les lletanies, però, que es digueren el dia 13 de gener, hom llegeix que foren "sine cantu"

\section{Exemplars de pregàries pel bon succés del setge de Viena. f. 156.}

Tingueren lloc el 8 d'octubre de 1683, a petició del rei Carles II. Després de nona es va exposar el Santíssim, sense cantar les lletanies, en canvi, cantaren l'ofici "De tempore belli". Les lletanies es cantaren durant la reserva, a les cinc de la tarda. Els dies següents, repetiren les susdites pregàries les parròquies i convents. El dia 17, després de les pregàries, es féu processó general, amb el mateix recorregut del dia de Corpus. Pel que fa a cant, només consta que cantaren les lletanies, invocant, com s'ha dit en altres ocasions, els patrons i titulars de les esglésies, convents i capelletes per on passava la processó.

\section{Acció de gràcies per la victòria obtinguda en el susdit setge de Viena. f. 157v.}

El 12 de desembre de l'esmentat any 1683, el qual coincidia amb el tercer diumenge d'advent, es digué l'ofici del diumenge corrent i, després, es cantà la lletania, tot fent processó per l'església i el claustre, també a petició del rei Carles II, en acció de gràcies per la victòria obtinguda a Viena. El diumenge següent, 19 de desembre i quart d'advent, a petició de la Ciutat, es digué un altre ofici amb la mateixa intenció, el qual fou "ab molta solemnitat". Es digué la Missa de SS. Trinitate pro gratiarum actione, malgrat tractar-se d'un diumenge d'advent. Després tingué lloc la processó, només per dins del temple i cantant el Te Deum. El dia 21 feren processó general, com el dia de Corpus. No es diu què varen cantar, però dels cantors es diu que anaren davant dels canonges. El dia següent, celebraren un aniversari solemne, també a petició de la Ciutat, pels qui moriren en la batalla del susdit setge de Viena.

Els apartats següents no tenen cap interès especial, pel que fa a la música: 
JOSEP PAVIA I SIMÓ

Exemplars de Pregàries pel bon succés de la guerra contra França. f. 158v- i 171.

Actio de gratias per la victoria obtinguda dels francesos en lo siti de Girona, f. 159v.

Exemplar de entredit. f. 160v.

Exemplars de Pregarias per la plaga de la llagosta. f. 164-168.

Exemplars de funerarias per la Reyna de Esp ${ }^{a}$. f. 169.

Te Deum per lo feliz arribo de la Reyna nova esposa. f. 175.

Combregà i enterro de un escolà de Grana, f. 168v.

Exemplars de Pregarias per ocasio de la malaltia del Rey y Actio de gratias per la millora.f. 176.

Exemplar de Combregar y mort del Archabisbe de Tarragona. f. 178.

Mort del emperador Joseph ividem. f. 178.

\section{Calendari}

«Chalendari de tots / los Mesos y Dias del Any / en que se asseñala en cada di / ada en particular la solemnitat / que li convindra y añadint lo / que tindra de spesial y particular / ademes del que sobre esta notat». Cap. 14, f. 55ss.

Gener (f. 55)

1. Circumcisio Dni Duplex secunda classis $^{10}$. No es canta res a cant d'orgue. Després de vespres, estació a la capella de St. Esteve.

2. Octava S. Stephani Dup. min. per annu[m]. Aniversari amb solemnitat. Estació, després de vespres, a la capella de St. Joan.

3. Octava S. Ioannis Duplex minus. Estació, després de vespres, a la capella dels Sants Innocents.

4. Octava SS. Innocentium Dup. min.

5. Vigilia Epiphaniae Semid. Malgrat tractar-se d'una festa semidoble, hi ha orgue. És molt curiós el cerimonial per al cant de l'introit (Dum medium silentium), el qual entonen el dormitorer, més dos doctors, des del presbiteri, estant darrera, però, de l'altar i segueix el cor, mentre ells passen al davant de l'altar, per entonar el salm de l'introit, el qual prossegueix el cor, mentre ells s'acosten a la porta del cor que mira a l'altar, on entonen el Gloria Patri, el qual respon tot el cor. Mentrestant, ells es situen davant del faristol major per prosseguir com en els oficis normals. Les vespres són de doble major de primera classe. Estació, després de vespres, a una capella del claustre, no especificada en el manuscrit. El Magnificat és a cant d'orgue. Si la vigília s'escau en diumenge, es canten les laudes i la prima, l'introit, però, s'interpreta en la forma explicada més amunt. ré les cometes.

10. Mantinc el títol i la categoria litúrgica de les festes com al manuscrit, ho posaré, però, en cursiva i m'estalvia- 
6. Epiphania Dni. Dup. Maius 1.a Classis. És molt curiós el ritual per al cant del primer salm del tercer Nocturn. L'ofici es canta a cant d'orgue a dos cors. Les segones vespres s'acostumen a dir cantades a cant d’orgue, exceptuant-ne les antífones i l'himne, com a les segones vespres de la Concepció.

7. S. Raymundi Dup. Ma 2. clas. A matines, laudes i prima es diu tot resat. S'entra a tèrcia a les vuit i entonen els capiscols "more solito". Després de la lletania, es diu l'ofici cantat a cant pla. Acabat l'ofici, s'inicia la processó cap a Sta. Caterina, tot cantant el Te Deum, per assistir a l'ofici que s'hi celebra (i que sol dir el prior) amb molta solemnitat i, acabat l'ofici, s'entornen a la catedral, tot cantant novament el Te Deum.

8. fins al 12 inclòs Semid. per ser els dies de l'octava d'Epifania i, per aquesta raó, també hi ha orgue.

13. Lo dia de la octava dup. min. Després de vespres, es fa estació a la capella del Patrocini per St. Hilari. Se acostuma fer aniversari amb solemnitat.

14. S. Hilarij. Semid. Després de vespres, es fa estació al claustre per S. Maure.

15. S. Pauli 1. Heremito. Semid.

16. S. Marcelli. Semid. Després de vespres, es fa estació a la capella de St. Antoni.

17. S. Antonij Abb. Dup. min. Aniversari amb solemnitat.

18. Cathedr. S. Petri Roma. Dup. min. Aniversari amb solemnitat.

19. S. Canuti Semid. Després de vespres, es fa estació al claustre per St. Sebastià.

20. Dup. min. SS. Fabiani et Sebastiani. A matines, laudes i prima es diu tot resat. S'entra a tèrcia a vuit hores i tèrcia, sexta i nona es diuen cantades. En començar sexta, s'ha de començar també l'ofici a l'altar major i es diu com està notat per al dia de Sta. Madrona, a 15 de Març. Després de l'ofici i la lletania, els quals han d'acabar a un mateix temps, parteix la processó per anar a St. Sebastia, cantant el Te Deum, el qual entonen els capiscols i el canonge més antic de cada cor. S'hi va per la Bòria, carrer de Montcada i Vedriaria. En arribar la Processó a St. Sebastià, es diu un ofici amb molta solemnitat, a cant d'orgue, el qual celebren els administradors del Col·legi de St. Sever. Al partir de St. Sebastià, els susdits capiscols entonen altre cop el Te Deum. La processó, ara, torna pel Regomir.

21. S. Agnetis Dup. min. Després de vespres, es fa estació a la capella del Roser pels Sants Vicens i Anastasi.

22. SS. Vincent. et Anasta. Semid.

23. S. Ildefonsi Dup. min. Aniversari amb solemnitat.

24. S. Thimotei Semid.

25. Conversio S. Pauli Dup. min.

26. S. Policarpij Semid.

27. S. Ioannis Crisostomi Dup. min. Aniversari amb solemnitat.

28. S. Iuliani Dup. min. Cum octava. I, també, festa de St. Valeri.

29. S. Fran.ci de Sales Semid.

30. S. Martina. Semid. 
31. S. Petri Nolasco Dup. Majus 2. clas. Tant l'ofici, com el Magnificat d'ambdues vespres, es canta a cant d'orgue a dos cors.

Febrer (f.60)

1. S. Ignatij Mart. Semid. Després de vespres, es fa estació a Sta. Eulàlia.

2. Purificat. B. M. V. Dup. Majus 2. clas. Benedicció i distribució de candeles, la qual fa, ordinariament, el bisbe. Mentre es fa la distribució, els capiscols, un pabordre, un doctor, un beneficiat vell i un de jove de cada cor, convidats pels capiscols, resten en el cor per cantar l'antífona Lumen ad revelationem i el càntic Nunc dimittis i, finalment, van ells també a prendre la cera. Després de la distribució, es fa la processó, acabada la qual es diu l'ofici a cant d'orgue. Després de vespres, es fa estació a Sta. Eulàlia.

3. De 7ma. die infra oct. S. Juliani. Semid.

4. De octava S. Juliani Dup. min.

5. S. Agatha Semid].

6. S. Dorothere Simp.

7. S. Romualdi. Dup. min.

8. S. Joannis de Mata Dup. min.

9. S. Apollonia Simp.

10. ferial.

11. ferial. Vespres de S. Eulàlia Patrona de la catedral. Dup. maj. p.a classis. El Magnificat es canta a cant d'orgue. Després de vespres, es fa estació a Sta. Eulàlia. i immediatament després de completes, comencen les matines, les quals es diuen cantades amb solemnitat.

12. S. Eulalice V. et M. Patron. Eccla. Dup. Ma. 1. Clas. Cum octava. Després de l'ofici, es fa la processó per la Llibreteria i la plaça del Rei. Es costum cantar tots els salms de les segones vespres a cant d'orgue, com també el Magnificat, però les antífones i l'hymne a cant pla. La resta, com en les segones vespres de la Concepció.

13. 14. 15. 16. 17. 18. De infra octau. S. Eulalice. Semid. Si coincideix, però, en diumenge, té aquest la preferència.

19. De octau. Dup[lex] min. Després de vespres, es fa estació a Sta. Eulàlia.

20. 21. ferial.

22. Cathedr. S. Petri Antiochice Dup. min.

23. Vigilia S. Mathice. ferial.

24. S. Mathice Apost. Dup. Ma. p. annum. No hi ha processó, ja que només se'n fa quan és un doble major 1. vel 2. classis, o, de festa "de colent.".

25. Si es Bixest (sic) S. Mathice. y sino ferial.

26. 27. 28. ferial. 
$\operatorname{Març}$ (f. 63)

1. 2. ferial.

3. SS. Hementerji etc. m.m. Dup. min.

4. S. Casimiri. Semid.

5. ferial. Es diuen les primeres vespres de St. Oleguer". Dup. Ma. 2. clas. El Magnificat es canta a cant d'orgue amb ministrils i, després de vespres, es fa estació a la capella de St. Oleguer. Tot seguit de completes, comencen les matines, cantades amb solemnitat, en les quals es solen cantar a cant d'orgue cinc responsoris, això és, el pimer, el tercer, el quart, el sisè i el setè, els altres tres, però, a cant pla, en la forma següent: per al segon i cinquè es conviden beneficiats i per al vuitè, el canonge més antic. El Te Deum, Benedictus i Salve també es solen cantar a cant d'orgue.

6. S. Olegarij Dup. Ma. 2. clas. Quan aquesta festa cau dins de la quaresma, s'entra a tèrcia a dos quarts de nou, perquè s'han de dir les vespres al matí. Es canta l'ofici a cant d'orgue a quatre cors amb ministrils i si es diuen les vespres al matí, comencen tot seguit de l'ofici i es canta el Magnificat a cant d'orgue a dos cors sense ministrils i es diuen a la capella de St. Tomàs. Aleshores, a la tarda es diuen completes cantades a cant d'orgue a 4 cors.

7. S. Thomae Aquin. Dup. min. Aniversari amb solemnitat.

8. ferial. Es diuen les primeres vespres de St. Pacià i es fa estació, després de vespres, a la seva capella.

9. S. Passiani Dup. Ma. 2. clas. Si cau dins de la quaresma, hom entra a tèrcia a dos quarts de nou. L'ofici es canta a cant d'orgue a dos cors.

10. SS. Quadraginta Martyrum Semid.

11. S. Francisca Romance Dup. min.

12. S. Gregorii Papa. Dup. min. Aniversari amb solemnitat.

13. 14. ferial.

15. S. Matronae Dup. min. Matines, laudes i prima són resades. S'entra a tèrcia a 7 hores i tèrcia, sexta i nona es diuen cantades. En començar sexta, s'ha de començar també l'ofici a l'altar major, el qual es diu resat i, mentrestant, el cor diu sexta, nona i lletania, procurant que lletania i ofici acabin a un mateix temps. Immediatament després, es diuen vespres, també cantades i, tot seguit, s'inicia la processó per anar a Sta. Madrona, tot entonant Te Deum "sens saltar ningun vers encara que de un vers a altre toquen los ministrils y despres los segos... fins al portal de St. Antoni...", des d'on es va en desfilada i sense cantar, fins a la Creu de Sta. Madrona, on es reprén la processó i el Te Deum. Essent arribats a l'església, els escolans diuen els versets i comença l'ofici. Canta la capella de la Seu a cant d'orgue. Acabat l'ofici, parteix la processó, després d'entonar l'antífona Ave regina calorum, i d'aquesta manera van fins a la sobredita Creu, des d'on es segueix en desfilada i sense cantar fins al Portal de St. Antoni, on es reprén la processó i el Te Deum.

16. ferial.

17. S. Patritij. Semid. 
18. S. Gabriellis Archangeli Dup. min. Després de vespres, es fa estació a la capella de St. Josep, al claustre.

19. S. Josephi Dup. Maius 2. Clas. L'ofici es cantat a cant d'orgue a dos cors.

20. S. Ioachim Dup. min. Aniversari amb solemnitat.

21. S. Benedicti Dup. min.

22. 23. ferial.

24. ferial. Després de vespres, es fa estació a Sta. Eulàlia, on es diuen completes a cant d'orgue, a més a més de les que es diuen al cor després de l'estació, com s'acostuma.

25. Anuntiationis B.M.V. Dup. Maius 2. Clas. Després de la lletania, es fa processó per l'església i claustre, com el 18 de desembre, en la festa de l'Expectació de la Mare de Déu, tot cantant pel claustre l'himne Ave Maris stella. Després de vespres, es torna a fer estació baix a Sta. Eulàlia.

26. 27. 28. 29. 30. 31. ferial.

Abril (f. 66)

1. ferial.

2. S. Francici de Paula. Dup. min.

3. ferial.

4. S. Isidori. Dup. min.

5. [Aquest dia no hi és, al manuscrit]

6. 7. 8. 9. 10. ferial.

11. S. Leonis Papa Dup. min.

12. ferial.

13. S. Hermanegildi Mart. Semid.

14. SS.Tiburtij Valeriani etc. mm. Simplex.

15. 16. ferial.

17. S. Aniceti Papa et Mart. Simplex.

18. 19. 20. 21. ferial.

22. Soteris et Cai mm. Semid.

23. S. Georgij Mart. Dup. min. Cum octava.

24. De $2^{a}$ die infra octavam S. Georgij. Semid. Després de vespres, es fa estació a la Capella de St. Marc.

25. S. Marci Evangelista Dup. Majus per annum. Matines, laudes i prima es diuen resades. La tèrcia comença a dos quarts de vuit i entonen els capiscols. En començar sexta, comença també la missa conventual, la qual es diu resada, mentre es diuen la sexta i la nona, procurant que aquesta i la nona acabin a un mateix temps. Al cor es canta l'antífona Exsurge Domine adjuva nos i s'entona el primer vers del salm 43 (Deus auribus nris. audivimus..., Gloria Patri... i es repeteix l'antífona. Es fa l'Asperges i s'entonen les lletanies, en dir, però, Sta. Maria, comença la processó a 1'Hospital General, on es fa l’ofici a cant d’orgue, el qual interpreta la capella de la 
Seu. Acabat l'ofici, els capiscols entonen l'antífona Regina caeli, la qual canten fins al portal, on entonen l'Ave maris stella, tot anant en processó cap a la Seu, repetint sempre a partir de la segona i sense dir la darrera, la qual es canta, un cop la processó és arribada dins de la Seu. Davant de l'altar de St. Marc, els capiscols entonen, drets, l'antífona Regina caeli, la qual es canta fins al presbiteri.

26. SS. Cleti et... mm. Semid.

27. 28. de infra octau. S. Georgi. Semid.

29. S. Petri Martyris Dup. min. Aniversari amb solemnitat.

30. de octava S. Georgij Dup. min.

Maig (f.68)

1. SS. Philipi et Jacobi Apost. Dup. Maius p annum. Després de l'ofici major, se'n diu un altre, a la capella dels mestres de cases, al qual no assisteix la clerecia, en canvi la capella hi canta a cant d'orgue.

2. S. Athanasij epi. Dup. min. Es diuen les primeres vespres de Sta. Creu, amb el Magnificat a cant d orgue. Tot seguit de completes, comencen les matines cantades amb solemnitat. Els tres primers responsoris de cada nocturn ${ }^{11}$ es canten a cant d’orgue, com també el Te Deum, el Benedictus i la Salve. Aquesta diada venen a cantar el segon responsori del primer nocturn un beneficiat de Sta Maria i un altre del Pi.

3. S. Crucis Dup. Majus 1a. classis et titularis Ecla. Comença prima a dos quarts de set i, al mateix temps, una missa resada a l'altar major, la qual celebra un canonge, acompanyat de diaca i mestre de cerimònies, com per St. Marc i Sta. Madrona. A les vuit es diu un ofici a la Canonja, a cant d'orgue. Excepcionalment, avui, com el dia de Nadal, es diuen dues misses a `altar major. Després de tèrcia i de les lletanies, té lloc la processó. L'ofici és cantat a dos cors a cant figurat i també el Magnificat, a vespres.

4. S. Monicae. Semid.

5. de $3^{a}$ die infra octava[m] S. Crucis Semid.

6. S. Ioannis ante Porta[m] Latina[m]. Dup. min. Aniversari amb solemnitat.

7. S. Stanislai, Mart.. Semid.

8. Aparitio S. Michaellis Dup. min. Aniversari amb solemnitat.

9. S. Gregorij Nazianceni. Dup. min.

10. octava S. Crucis Dup. min.

11. ferial.

12. SS. Nerei Achilei etc. m.m. Semid.

13. ferial.

14. S. Bonifatij. Mart. Simplex.

15. ferial.

11. Això diu el manuscrit, però crec que s'ha d'entendre: el primer responsori de cada nocturn. 
16. S. Ubaldi, epi. Simplex.

17. ferial.

18. S. Venantij, Mart. Semid.

19. S. Petri Celestini Papa et Conf. Dup. min.

20. S. Bernardini Cenensis. Conf. Semid.

21. 22. 23. 24. ferial.

25. S. Mariae Magdalena de Pazis. Semid.

26. S. Philippi Neri Conf. Dup. min.

27. S. Ioannis Papce Simplex.

28. 29. ferial.

30. S. Ferdinandi Conf. Dup. min.

31. S. Petronilae Virg. Simplex.

Juny (f. 71)

1. ferial.

2. SS. Marcelli Petri etc. m.m. Simplex.

3. 4. y. 5. ferial.

6. S. Norberti. Dup. min.

7. y. 8. ferial.

9. SS. Primi et Feliciani m.m. Simplex.

10. ferial. Estació per sant Bernabé, després de vespres.

11. S. Bernaba Apost. Dup. min.

12. SS. Basilidis Cyrini etc. m.m. Simplex.

13. S. Antonij de Padua Conf. Dup. min.

14. S. Basilij mag. epi. Dup. min.

15. SS. Viti Modesti etc. m.m. Simpl.

16. y. 17. ferial.

18. SS. Marci et Marcelliani m.m. Simpl.

19. SS. Gervasi et Protasi m.m. Simpl.

20. S. Silverij Papa et mart. Simpl.

21. ferial.

22. S. Paulini epi. et Conf. Simpl.

23. ferial. Vigília de S. Joan. Després de vespres, estació a la capella de St. Joan.

24. S. Ioannis Batt.a Dup. Ma. 2dce. clas. Ofici a cant d’orgue.

25. de 2. die infra oct. S. Joannis Semid.

26. SS. Ioannis et Pauli m.m. Semid.

27. de 4. die infra octau. Semid.

28. S. Leonis Papae. Semid. Vigília de St. Pere. A vespres, es canta el Magnificat a cant d`orgue i, després de vespres, es fa estació a la capella de St. Pere. 
29. SS. Petri et Pauli Apost. Dup. Ma. p.ce Clas. Cum octava. Després de la lletania, hi ha processó rodant el temple, durant la qual es canta el Te Deum. L'ofici és cantat a cant d'orgue a 2 cors. A vespres, el Magnificat també es canta a cant d`orgue.

30. Commemoratio S. Pauli Dup. min. Aniversari amb solemnitat.

Juliol (f. 72)

1. Octava S. Joannis. Dup. min. Després de vespres, estació al claustre, a la capella de la Visitació de Maria. Després de completes, es diuen matines cantades amb solemnitat de la Visitació, però no diu que es canti res a cant d’orgue, ni a vespres, ni a matines.

2. Visitationis B. M.V. Dup. Maius 2 da. clas. Hi ha processó, com el dia 17 de desembre, festa de l'Expectació de Maria i estació a S. Eulàlia, després de vespres.

3. de $5^{a}$ die infra octav. S. Petri. Semid. Estació, després de vespres, al claustre per la translació de S.Martí i no de Sta. Elisabet, encara que es diuen les vespres d'aquesta santa.

4. S. Elisabeth Regince Portug. Semid.

5. De $7^{a}$ die infra oct. S. Petri. Semid.

6. De octava SS. Petri et Pauli Apost. Dup. min.

7. ferial.

8. S. Margarita viduce Semid.

9. ferial.

10. SS. Septem fratrum mm. Semid.

11. S. Pii Papa et mart. Simplex.

12. S. Ioannis Gualberti Abbatis. Dup. min.

13. S. Anacleti papa et mart. Semid.

El dissabte abans de la $2^{a}$ dominica de Juliol, es fa estació a Sta. Eulàlia, després de vespres.

La dominica $2^{a}$ de juliol s'escau el trasllat segon de Sta. Eulàlia. Dup. Maius 2dce. classis. L'ofici és a cant d’orgue a dos cors. A vespres, no es canta res a cant d’orgue, però es fa estació a S.Eulàlia.

14. S. Bonaventura epi. Dup. min.

15. S. Henrici Imperatoris Conf. Semid.

16. Triumphi S. Crucis Dup. Ma. 2. clas. No es canta res a cant d’orgue. Després de vespres es fa estació al claustre, a St. Aleix.

17. S. Alexii Conf. Semid.

18. S Simphorosa cum 7 filiis m.m. Simplex.

19. B. M.de Monte Carmelo dup. min. Després de vespres, estació a l'altar de S. Margarida.

20. S. Liberatae v. et m. dup. min.

21. S. Praxedis v. Simplex. Estació a l'altar de Sta. Madalena, després de vespres.

22. S. Maria Magdalence Dup. Ma. 2da. classis. Ofici a cant d’orgue a l'altar de la santa. El Magnificat a vespres, es canta a cant d'orgue. 
23. S. Apollinaris m. Dup. min.

24. Vigilia S. Iacobi de ea. Després de vespres, estació al claustre.

25. S. Iacobi Apost. Dup. Ma. 2. classis, ab octava. Després de vespres, estació a la capella de la Concepció, al claustre.

26. S. Annae. Dup. ma. 2. clas. No es canta res a cant d’orgue. Després de vespres, estació a la capella de St. Miquel.

27. S. Cucuphatis mart. Dup. min.

28. SS. Nazarii, Celsi etc. m. m. Semid. Estació a Sta. Marta, després de vespres.

29. S. Marthae virg. Semid.

30. De octava S. Iacobi. Semid.

31. S. Ignatii Conf. Dup. min.

Agost (f.75v)

1. de die octaua S. Iacobi. Dup. min. Estació, després de vespres, a la capella de St. Pere.

2. S. Petri ad vincula dup. min. Estació a la capella de St. Esteve, després de vespres.

3. Inventio S. Stephani Semid. Estació, després de vespres, a St. Domènec.

4. S. Dominici Dup. ma. 2. clas. No es canta res a cant dorgue.

La dominica $p^{a}$ de Agost de B. M. de Mercede. Dup. min.

5. Dedicatio B. M. ad Nives Dup. min. Aniversari amb solemnitat, amb una absolta dins del cor. Després de vespres, estació a la capella de les ànimes i, després de completes, es diuen matines de la Transfiguració, cantades amb solemnitat, però no es canta res a cant d’orgue.

6. Transfigurationis D. N. J. C. Dup. Ma. 2. classis. El Manual diu expressament, que no es canta res a cant d'orgue.

7. S. Cayetani conf. Dup. min.

8. SS. Cyriaci etc. m. m. Semid.

9. SS. Iusti et Pastoris m. m. Dup. min. Després de vespres, es fa estació a la capella de St. Tomàs i St. Llorenç.

10. S. Laurentij m. Dup. Ma. 2. classis. No es canta res a cant d’orgue.

11. De Infra octau. S. Laurentij Semid.

12. S. Clarae v. Dup. min.

El dissabte abans de de la segona dominica d'agost, estació a la capella de St. Sever.

La dominica segona de Agost, Translationis S. Severi, dup. Ma. 2. classis. Es canta l'ofici a cant d'orgue. A les segones vespres, estació a l'altar major.

13. De infra oct. S. Laurent. Semid.

14. De infra oct. S. Laurent. Semid. et vigilia Assumptionis B. M. V. No es fa aniversari, sinó que es diu la missa o ofici de la vigília. Hi ha orgue. A vespres, es canta el Magnificat a cant d'orgue a dos cors. Després, es fa estació baix a Sta. Eulàlia.

15. Assumptionis B.M.V. Dup. Ma. p. ce classis. Després de sexta, es diu la lletania. L'ofici és cantat a cant d’orgue i va seguit de la processó, abans de la qual, però, dansa l'àliga. Durant 
la processó, es canta el Te Deum. Tornats al temple, es fa exposició del Santíssim i es canta nona, com el dia de l'Ascensió. L'himne es diu alternant el cor amb l'orgue, essent aquest qui fa la primera i la darrera estrofa/vers. El primer i el darrer salms es fan a cant d'orgue i el segon alternant el cor amb l'orgue, l'antífona el cor a cant pla, la "capitula" i l'oració el missa cantant i els versets dos doctors, "more solito". La Salve a cant d'orgue. Després, es fa la reserva, tot cantant el Tantum ergo. A les segones vespres, "omnia ut in primis".

16. S. Hyacinthi. conf. Dup. min.

17. de die octava S. Laurentij Dup. min.

18. de infra octau. Assumptionis Semid.

19. de infra octau. Assump. Semid. S. Magi Valeri. Després de vespres, estació al claustre, per St. Bernat.

20. S. Bernardi Abbatis. Dup. min.

21. De infra octau. Assumptionis Semid.

22. De octava Assump. Dup. min. .

23. Vigilia S. Bartholomei ferial. Després, estació al claustre.

24. S. Bartholomei Apost. Dup. Ma. per annum.

25. S. Ludovici Conf. Semid.

26. S. Zeferini mart. Simplex.

27. ferial. Després de vespres, estació a la capella de St. Oleguer per St. Agustí.

28. S. Augustini, epi. Dup. Ma. 2 classis. Ofici cantat a cant d'orgue a dos cors, com també el Magnificat, a les dues vespres. Després, estació a la capella de St. Joan.

29. Decollatio S. Ioannis. Dup. min.

30. S. Rosa v. Dup. min.

31. S. Raymundi non nati. Dup. min.

Setembre (f.78)

1. S. Agidij abbat. Simplex.

2. S. Stephani Conf. Semid.

3. 4. 5. y. 6. ferial.

7. ferial. S'entra a tèrcia a nou hores, com si fos dia de precepte. Després de vespres, estació a sta. Eulàlia.

8. Nativitatis B.M.V. Dup. Ma. 2. clas. Després de la lletania, processó, com el 2 de juliol. Ofici a cant d`orgue a 2 cors. Després de vespres, estació a Sta. Eulàlia. El Magnificat d'ambdues vespres, a cant plạ.

9. de infra octau. Semid. Hi ha orgue a l'ofici.

10. S. Nicolai de Tolentino Dup. min.

El diumenge infra octava, de Ssmo. Nomine B.M.V. Dup. min.

11. de infra octava. Semid. Hi ha orgue a l'ofici.

12. de infra octava. Semid. Com ahir. 
13. Similiter ut heri.

14. Exaltationis S. Crucis. Dup. Ma. 2. clas. Ofici a cant d`orgue a 2 cors i també el Magnificat d'ambdues vespres.

15. Octava Nativitatis B.M.V. Dup. min.

16. SS. Cornelij etc. m.m. Semid.

17. S. Petri de Arbues mart. Dup. min.

18. S. Thoma de Vilanova Semid.

19. SS. Ianuarij etc. m.m. Dup. min.

20. SS. Eustachij et etc. m. m. Dup. min. Després de vespres, estació a la capella de St. Pacià, per St. Mateu.

21. S. Mathei Apost. Dup. Ma. p[er] annum.

22. Impressio Stigmatum S.Fran.ci. Semid. Després de vespres, estació a la capella de la Magestat per Sta. Tecla.

23. S. Thecla v. et m. Dup. Ma. 2. clas. Ofici a cant d'orgue.

24. S. Lini papa et mart. Semid. Després de prima, absolta a la capella de Sta. Llúcia, a càrrec del beneficiat de Sta. Tecla.

25. ferial.

26. SS. Cypriani etc. m.m. Simplex. Després de vespres, estació al claustre, a la capella dels sants Metges.

27. SS. Cosma et Damiani m.m. Semid.

28. S. Vuinceslai mart. Semid. Després de vespres, estació a la capella de St. Miquel.

29. Dedicationis S. Michaellis Archangeli. Dup. Ma. 2. clas. Ofici i Magnificats a cant d`orgue. Estació a la capella de St. Geroni.

30. S. Hieronimi. Dup. Ma. 2. clas. S'entra a tèrcia a dos quarts de nou. Ofici a cant d’orgue.

Octubre (f. 81)

1. S. Remigij epi. Semid. Després de vespres, estació a la capella de l'Àngel Custodi.

2. Angelorum Custodum Dup. Ma. 2. clas. Ofici a cant d`orgue. Processó després de l'ofici, per la plaça de St. Jaume, Llibreteria i plaça del Rei. En iniciar-se la processó, els capiscols entonen el Te Deum.

3. ferial. Després de vespres, estació a la capella de St. Francesc, al claustre.

4. S. Fran.ci Dup. Ma. 2. clas. No es canta res a cant d'orgue.

La p.a Dom.ca de 8.bre SSmi. Rosarij B.M.V. Dup. min.

5. SS. Placidi etc. m.m. Simplex.

6. S. Brunonis Conf. Dup. min. Aniversari amb solemnitat.

7. S. Marci Papa et Conf. Simplex.

8. S. Birgitae viduce. Semid. Després de vespres, estació a l'altar de St. Dionís.

9. SS.Dionisij et sociorum m.m. Semid. 
10. S. Fran.ci Borgia conf. Dup. min.

11. y. 12. ferial.

13. S. Eduardi Conf. Semid.

14. S. Calixti m. Semid.

15. S. Theresice virg. Dup. min. Aniversari amb solemnitat.

16. ferial.

17. S. Heduvigis vidua. Semid.

18. S. Luca evang. Dup. Ma. p[er] annum. No hi ha processó, si no s'escau en diumenge.

19. S. Petri de Alcantara. Semid. Tot resat.

20. ferial. Després de vespres, estació a la capella de Sta. Llúcia, per Sta. Ursula.

21. S. Ursula. Dup. min.

22. ferial. Després de vespres, estació a la capella de Sta. Eulàlia.

23. p.a translatio S. Eulalix. Dup. Ma. 2. clas. Ofici cantat a cant d’orgue a 2 cors i també el Magnificat de les primeres i segones vespres. Després de vespres, estació a Sta. Eulàlia.

24. S. Raphaellis Archang. Dup. min. Després de vespres, estació a la capella de St. Marc.

25. SS. Gavini Prothi etc. m.m. Dup. min.

26. S. Petri Paschasii Dup. min.

27. Vigilia SS. Simonis et Judae. De ea. Ferial. Després de vespres, estació al claustre, a la capella de Tots els Sants.

28. SS. Simonis et Juda Apost. Dup. Ma. per annum. Després de vespres, estació a St. Narcís.

29. S. Narcisij mart. Dup. min.

30. ferial.

31. ferial. Vigilia Omnium Sanctorum. De ea. Però, si hi ha sepultura, es diu la conventual de la sepultura i la matinal de la vigília. Després de vespres, estació al claustre, a la capella de Tots els Sants. El Magnificat es canta a cant d’orgue a 2 cors i també a les segones vespres.

Novembre (f.83)

1. Omnium Sanctorum Dup. Ma. p.ae classis. Hi ha processó per l'església, després de la lletania. L'ofici es canta a cant d'orgue. Després del Benedicamus Domino de les segones vespres, els capiscols i els dos canonges que tenen capa (blanca), la canvien per la negra, per a les vespres de morts, les quals també es diuen amb solemnitat "sub ritu dup. ma. p.æ vel 2dæ. clas.", el Magnificat, però, es canta a cant pla.

2. de $2^{a}$ die infra octau. Omnium SS. Semid. Les matines i laudes es diuen resades, però, després del Benedicamus de laudes i de prendre la capa negra, comencen les matines de morts "sub ritu dup. majoris p.æ vel 2dæ. classis". No oficia el domer major, sinó el menor. Els capiscols conviden per a les antífones, però ells entonen els salms, com està notat al cap. 6. que tracta de les matines cantades amb solemnitat. També han d'invitar per als responsoris, d'aquesta 
manera: un dr. jove per al primer, un beneficiat jove per al segon, un canonge jove per al tercer, dos beneficiats dels antics per als quart i cinquè, un canonge dels antics per al sisè, el beneficiat més antic per al setè, el dr. més antic per al vuitè i el canonge més antic per a l'últim. El succentor és qui convida per a les lliçons, com també està notat al cap. 6. Els canonges més antics invitats per al darrer responsori, baixen davant del faristol major a dir, en acabar el darrer salm de laudes, a dir: Audivi vocem, etc. i el requiescant in pace, després de la col·lecta del Benedictus. Segueix l'hora de prima, la qual també és cantada. L'ofici o aniversari, celebrat per canonges, comença al punt de les vuit, baix a Sta. Eulàlia, estant el cor de la música a la troneta i tota la clerecia al cor. Acabat aquest ofici, es fa una absolta dins del cor i, acabada la qual, els dos canonges més antics, un de cada cor, baixen junt al túmul per dir Requiescant in pace. A nou hores, s'entra a tèrcia i, després de la lletania i de portar el túmul dalt al presbiteri, comença l'ofici, el qual és cantat a cant figurat a dos cors, estant els cors de la música baix al cor. Acabat l'ofici, es fan tres absoltes, una sobre el vas dels canonges, tota a cant d'orgue, altra al vas dels bisbes $\mathrm{i}$ altra al vas dels canonges, ambdues a cant d'orgue i a cant pla. Després es roda tota l'església i tot el claustre, fent absoltes a cant pla, això és, quatre dins de l'església: una davant de la sagristia, altra davant de l'altar de les ànimes, la tercera davant del portal major i la quarta davant de St. Gregori. Altres quatre es fan als quatre costats del claustre. Després, es torna a entrar a l'església per sortir per la porta de sota l'orgue, es tomba cap a Montjuich, capella de Sta. Llúcia i portal major de l'església, fent també absoltes a cant pla, això és, una davant del Palau del Rei, altra davant de la Carnisseria, altra a Montjuich, altra en la capella de Sta. Llúcia, altra davant de la casa de l'Ardiaca major i la darrera dins de l'església, entre el portal major i el cor, essent la que comença per Libera me Dne. i acaba amb el requiem aternam, etc.

3. de infra octau. omnium SS. Semid. Es fa aniversari pel rei En Jaume, amb túmul i es canta a cant pla. Després de l'aniversari es fa una absolta davant de Sta. Eulàlia i després, 1'"absolta de la penitencia, etc."

4. S. Caroli epi. etc. Dup. min. Es fa aniversari amb solemnitat, amb una absolta al cor.

5. de infra oct. omnium SS. Semid. Magnificat a cant d orgue a quatre cors, contant el dels ministrils. Després de vespres, estació a la capella de St. Sever.

6. S. Severi epi. et mart. Dup. Ma. 2. clas., cu[m] octau. Després de matines, es diu un ofici a la capella de St. Sever, a cant d’orgue, a la qual acostumen assistir-hi alguns canonges, en el cor que es monta davant de la susdita capella. La tèrcia comença a dos quarts de deu, perquè hi ha prohomenia. Després de la lletania, comança l'ofici, cantat a cant d'orgue a tres cors, ofici seguit de processó per de fora de la catedral, rodant-la i començant per la part de la Inquisició. El Magnificat es canta com a les primeres vespres, el qual es va a acabar a l'altar major, on es troba el cos del sant i s'hi fa estació.

7. de infra octau. omnium SS. Semid. Després de vespres, estació al calustre, a la capella de Tots els Sants "y se donen nesples".

8. de octaua Omnium SS. Dup. min. Després de vespres, estació a la capella del St. Crist, darrera de l'altar major.

\section{Dedicatio Basilica Salvatoris. Dup. min.}


10. de infra octau. S. Severi Semid. Després de vespres, estació al calustre, per St. Martí.

El dissabte abans de la segona dominica de novembre, les vespres són del Patrocini de $\mathrm{N}^{\mathrm{a}}$. $S^{a}$. "sub ritu duplici maj. $2^{\text {a }}$ classis" i, després de vespres, es fa estació baix a Sta. Eulàlia.

La segona dominica de novembre, Patrocinium B. M. V. dup. maj. 2da. classis. Després de les segones vespres, es va a fer estació baix a Sta. Eulàlia. L'ofici es canta a cant d'orgue. S'entra a tèrcia a dos quarts de deu, per haver-hi prohomania.

11. S. Martini epi. Dup. min. Aniversari amb solemnitat.

12. S. Martini mart. Semid. Després de vespres, estació a la capella de St. Sever.

13. De octau. S.Severi. Dup. min.

14. S. Didaci Conf. Semid.

15. S. Eugenij mart. Dup. min.

16. ferial.

17. S. Gregorii Tha[u]maturgi epi. Semid.

18. Dedicatio Sedis Barchinonen. Dup. Maj. 2a. clas. cum octau. in civitate tantu[m]. L'ofici es canta a cant d'orgue a dos cors, com també el Magnificat "in utriusque (sic) vesperis".

19. S. Elisabeth vidua. Dup. min.

20. S. Felicis de Valois conf. Dup. min. Després de vespres, estació baix a Sta. Eulàlia.

21. Prasentationis B.M.V. Dup. maj. 2ae. class. Es fa processó, abans de l'ofici. En ser davant de la sagristia, tothom s'agenolla i el capiscol i el succentor entonen, també agenollats, l'himne Ave maris stella, acabada la primera estrofa del qual, prosegueix la processó pel claustre tot cantant el susdit himne, fins a l'altar de la Concepció, on es tornen a agenollar i canten l'estrofa Monstra te esse matrem, acabada la qual, la processó reprén cap a l'església. Tingueu en compte, que es poden repetir coples, llevat les suara esmentades. Un cop dins del temple, es fa estació davant del cor. No es canta res a cant d`orgue i, després de vespres, estació baix a Sta. Eulàlia.

22. Festa de St. Valeri S.Cecilice v. et m. Dup. min. Estació, després de vespres.

23. S. Clementis papa et mart. Semid. Estació, després de vespres.

24. de infra octau. Dedicationis. Semid. Després de vespres, estació a la capella de St. Marc. Vel Dedicatio Basilica SS. Petri et Pauli. Dup. min. fuit 18 huius.

25. de die octau. dedicationis. Dup. min.

26. Desponsationis.B.M.V. Dup. min.

27. S.Catharinae v. et mart. Dup. min. Aniversari amb solemnitat.

28. ferial.

29. Vigilia S. Andrea apost. De ea ferial. Estació, després de vespres a la capella dels mestres de cases.

30. S. Andrea Apost. Dup. maj. per annu[m].

Desembre (f. 88)

1. ferial. 
2. S. Bibiance v. et mart. Semid. Bàrbara.

3. S. Francisci Xaverii conf. Dup. min. Estació, després de vespres a la Magestat p[er] Sta.

4. y. 5. ferial, si és advent, altrament: 4. S. Barbara. Simplex.

5. Sti. Sabbe (sic) Abbatis, també simplex. Estació a la capella del Patrocini, p[er] St. Nicolau.

6. S. Nicolai epi. Dup. min. Després de vespres, estació al calustre, per St. Ambròs.

7. S. Ambrosii epi. Dup. min. Aniversari amb solemnitat. Primeres vespres "Conceptionis B. M. V. Dup. Ma. 1. clas., a diferència de l'Església universal, la qual la celebra de "dob. m. 2. clas." Després de vespres, estació al calustre, a la capella de la Concepció. L'himne i el Magnificat es canten a cant d'orgue. Després de completes, es comencen les matines cantades amb solemnitat.

8. Conceptionis B. M. V. Dup. Ma. 1. class. Cum octava. S'entra a tèrcia a dos quarts de deu, ja que hi ha prohomania i, a més, hi acostumen d'assistir-hi el lloctinent i el bisbe acostuma celebrar de pontifical. Després de l'ofici, hi ha processó per fora de l'església, això és, per la plaça de St. Jaume, Llibreteria i plaça del Rei. En començar la processó, els capiscols, juntament amb els canonges que tenen capa, entonen, agenollats, al presbiteri i darrera del gremial, el $T e$ Deum $^{12}$. Les segones vespres comencen tot seguit de la funció del matí i és costum cantar tots els salms, l'himne i el Magnificat a cant d'orgue i totes les antífones a cant pla. Després de vespres, estació baix a Sta. Eulàlia. Reliqua ut in dup. ma.1. clas.

9. S. Leocadia virg. et mart. Dup. min.

10. de infra octau. Conceptionis. Semid. Sta. Eulalia Emerita virg. et mart. Dup. min.

11. S. Damassi Papae et conf. Semid. Després de vespres, estació al claustre.

12. De infra octau. Conceptionis. Semid. Després de vespres, estació a la capella dels mestres de cases, de St. Pere i St. Feliu per Sta. Llúcia.

13. S. Lucia virg. et mart. Dup. min. Després de vespres, estació a la capella de Sta. Llúcia.

14. de infra octau. Conceptionis Semid. Les vespres es diuen de cap d'octava de la Concepció, amb la mateixa solemnitat com si fos doble major de segona classe. Després de vespres, estació al claustre, a la capella de la Concepció.

15. de die octava Conceptionis Dup. min. La tèrcia comença a dos quarts de deu, perquè hi ha prohomania. No entonen els capiscols, sinó que, després de la lletania conviden dos canonges, un de cada cor, els quals tindran capa en l'ofici, juntament amb altres sis, com si fos doble major. "Se canta a cant de orga ab molta solemnitat". Després de l'ofici, hi ha processó pel claustre, en la qual, abans de començar, els capiscols juntament amb els dos canonges joves que hau-

12. En aquest punt, el manuscrit porta una nota al text i una altra al marge, les quals són del tenor següent: La del text: "Nota que en lo any 1684 se feu dita Professo p[er] la Igla. y Claustro, per causa del molt vent q[ue] feya en lo temps que se havia de fer". La del marge: "Nota que en lo any 1722 ha causa de una eclipse de sol que se deya que havia de ser urritble y ... gran, resolgue lo Capitol entrar a orar a 2.quars de 9. y fer seguidament tota la funcció p[er] la causa de la pluja y ... dia se feu la Professo per la Iglesia y Claustro per resolució del Capitol presa en un Parlament abans de comensar lo ofici”. 
ran tingut la capa a l'ofici, entonen, agenollats al peu de l'altar major, el Te Deum. A les segones vespres, es canta tot a cant d'orgue o a cant pla, com el dia de la Concepció, exceptuant-ne l'himne, el qual es diu a cant pla, tot alternant el cor i l'orgue. Després de vespres, estació baix a Sta. Eulàlia.

16. Ferial ${ }^{13}$.

17. Ferial. Vespres Expectationis B. M. V. Dup. Ma. 2. clas. En començar el domer la col-lecta, els capiscols conviden el Capítol i clergat perquè baixin davant del faristol major a cantar l'antífona $O$ Sapientia, per la commemoració de la fèria. Després de vespres, estació a Sta. Eulàlia.

18. Expectationis B. M. V. Dup. ma. 2. clas. Després de la lletania, es fa processó per l'església i el claustre. En ser davant de la sagristia, tothom s'agenolla i el capiscol i el succentor entonen, també agenollats, l'himne Ave maris stella, acabada la primera estrofa del qual, prosegueix la processó pel claustre tot cantant el susdit himne, fins a l'altar de la Concepció, on es tornen a agenollar i canten l'estrofa Monstra te esse matrem, acabada la qual, la processó reprén cap a l'església. Tingueu en compte que, es poden repetir coples, llevat les suara esmentades. Un cop dins del temple, es fa estació davant del cor. L'ofici es canta a cant pla. A les segones vespres, els capiscols conviden canonges perquè baixin a cantar l'antífona $O$ Adonai. Després de vespres, estació baix a Sta. Eulàlia.

19. Ferial. A vespres, un cop entonat l'himne, el dormitorer ha d'invitar la dignitat més preheminent del cor que presideix, perquè entoni l'antífona $O$ radix Jesse, i tots els residents, llevat del domer, el dormitorer i el canonge que ha entonat l'antífona, baixen a cantar-la davant del faristol major. Si assisteix el bisbe, li correspon a ell entonar l'antífona.

20. Vigilia S. Thoma Apost. ferial. Les vespres S. Thoma dup. ma. p[er] annum. En començar la col·lecta, els capiscols conviden per cantar l'antífona $O$ clavis. Després de vespres, estació al claustre a la capella de St. Antoni de Pàdua per St. Tomàs apòstol.

21. S.Thoma Apost. Dup. maius per annum. S'ha d'advertir als cantors que assisteixin a l'ofici, per cantar el credo que es diu "de la monja". A vespres, els capiscols també han de convidar per l'antífona $O$ oriens.

22. Ferial. A vespres, es procedeix, pel que fa al cant de l'antífona $O$ rex, com els dies anteriors.

23. Ferial. A vespres, es procedeix, pel que fa al cant de l'antífona $O$ Emmanuel, com els dies anteriors.

13. L'any 1686, la festa de la Concepció es va transferir al dia 10, pel fet de coincidir amb el segon diumenge d'advent $\mathrm{i}$ igualment l'octava, celebrant-se la festa amb la mateixa solemnitat del dia 8 , com s'ha notat, però la vigília de l'octava, això és, el dia 16 i el de l'octava o dia 17, s'introduiren algunes variants, com: Les vespres del dia 16 no foren de fèria, sinó que es cantà l'ofici minoret, amb solemnitat de doble major de segona classe, llevat que no es duplicaren les antífones... Es va cantar l'himne Ave maris stella i el Magnificat a cant d'orgue. Després de dir la col-lecta i fer la commemoració de Tots Sants, s'anà a fer estació a la capella de la Concepció. El manuscrit diu que, després d'això, encara es van cantar les vespres $\mathrm{i}$ completes de fèria $\mathrm{i}$ es digueren les completes del minoret resades. A matines, laudes $\mathrm{i}$ prima, es digué tot resat. A tèrcia sexta i nona, es va cantar com els dies ferials. L'ofici, però, es digué de la Concepció, cantat a cant d'orgue amb molta solemnitat i després es féu la processó pel claustre, com està notat el dia 15 de setembre. Les segones vespres foren de l'Expectació de Maria SS. amb la solemnitat explicada el susdit dia 15 de setembre (fol. 90 ). 
24. Vigilia Nativitatis Domini De ea. Les matines es diuen resades de la fèria, sense dir el minoret. Les laudes i prima es diuen amb rite doble i es canten com en els dobles menors, ara bé, a prima baixa tota la clerecia a cantar els versets, com en els dobles majors i canta la Kalenda un canonge, amb la solemnitat que prescriu la rúbrica. Acabada prima, el succentor fa una platiqueta en llatí i, després, convida els canonges per a les lliçons de les matines següents i als que han de dir la Missa del Gall i la de l'Aurora, amb llurs ajudants. Tèrcia i hores es diuen, a l'hora convinguda, com en els dobles menors. Acabada la lletania, dos canonges invitats pels capiscols, amb capa i bordó, pujen a l'altar major, darrera del qual i ajudats pel dormitorer entonen l'introït, com més llargament s'explica la vigília de l'Epifania, el 5 de gener. La resta és com en els dobles menors. A vespres, es celebra de la Nativitat de N. S. J. C., doble major de primera classe, amb el Magnificat a cant d`orgue.

25. Nativitatis D.N.J. Duplex ma. prima classis. Cum octava. Les matines comencen al punt de la mitjanit i es diuen cantades amb molta solemnitat. Mentre es diu la primera volta l'invitatori Christus natus est nobis..., tots romanen agenollats. Quant als responsoris, el primer de cada nocturn, s'acostuma a cantar a cant d'orgue; el segon el canten dos capellans que venen de les parròquies — un de Sta. Maria i un del Pi-; el tercer dos canonges — un de cada cor, invitats pels capiscols - i així tots els responsoris que no es canten a cant d'orgue; el darrer, però, el diu el canonge més antich. Per al sisè, això és, Sancta et immaculata..., conviden tota la clerecia, perquè baixi a cantar-lo davant del faristol major. Acabat el Te Deum, comença tot seguit la Missa del Gall, en la qual dos doctors pujen a l'altar a entonar el Gloria al missa cantant. Acabada la missa es canten laudes i prima, tot fent la doma el domer menor i els suara esmentats doctors conviden per entonar les antífones, però ells entonen els salms, com ho acostumen de fer els capiscols en els dobles majors. A sis hores, es diu la missa de l'Aurora, a cant d'orgue, baix a Sta. Eulàlia. S'entra a tèrcia «a nou horas y mitja". L'ofici es canta a cant de orgue, estant tota la cantoria baix al cor. El Magnificat de les segones vespres és cantat a cant d’orgue. Després, estació a la capella de S. Esteve.

26. S. Stephani Prothomartiris Dup. ma. 2. classis. Cum octava. S'entra a tèrcia a tres quarts de nou. Després de la lletania, s'entona el Te Deum, estant tots agenollats dins del cor i comença la processó, la qual dóna la volta a la catedral per de fora, començant per la Inquisició i, després també fan la volta per dins del temple, començant per la part de St. Sever i es fa estació abans d'entrar al cor. L'ofici es canta a cant d`orgue i després de vespres, hi ha estació a S. Joan.

27. S. Joannis Apost. et Evangelista Dup. ma. 2. classis. Cum octava. L'ofici es canta a cant pla. Després de vespres, estació a la Capella del Perdó, o dels Sants Innocents. A completes comencen a oficiar els beneficiats joves i els escolans «del modo que esta prescrit en un llibre que hi ha en la sacristia de las serimonias que han de fer dits Beneficiats y escolans en lo dia dels Innocents".

28. SS. Innocentium. Dup. ma. 2. classis. Cum octava. Les matines, laudes i prima es diuen resades. La tèrcia, sexta, nona, processó i ofici es fa com a les altres festivitats de doble major de primera classe, "si no es que los beneficiats joves y escolans fassan los Innocents que 
a les hores ells fan las functions dels cabiscols y canonges tant a horas com en la professo y offici y vespres conforme esta disposat en lo sobredit llibre.

29. S. Thomae Canturiensis mart. Semid.

30. Si és dissapte, es fa l'ofici d'octava, com disposa la rúbrica, "sub ritu semiduplici", com s'ha dit del dia de St. Tomàs Cantuariense. Després de vespres, estació a la capella de St. Silvestre.

31. S. Silvestri Papa et conf. Dup. min. Després de la lletania, processó per l'església. A vespres, doble major de segona classe "De Circumcisione Dni. Nri. JChti.

El diumenge infra octava de Nadal, es fa l'ofici de semidoble i es canten laudes i prima. 